\title{
Değişim ve Devamlılık: Türkiye'de Vatandaşlık ve Sosyal Bilgiler Ders Kitaplarında Asker-Sivil İlişkileri ve Darbeler $(1950-2012)^{*}$
}

\author{
Change and Continuity: Military-Civilian Relations and \\ Coups in Turkey's Citizenship and Social Studies Textbooks \\ (1950-2012)
}

\begin{abstract}
Abdulkerim ŞEN**
Öz: Türkiye uluslaşma ve modernleşme tarihinin en önemli aktörlerinden birisi olan ordunun devlet sistemi içerisindeki politik otonomisi ve politikaya müdahil eylemleri demokrasi norm ve ilkeleriyle bağdaşmayan bir görünüm sergilemiştir. Ordu, demokrasi normlarına göre bir anomali teşkil eden bu konum ve eylemlerini, eğitim gibi kamusal diskur üretme araçları ile meşrulaştırma yoluna gitmiştir. Mevcut eğitim araştırmaları, Türkiye'de ordunun anti-demokratik konum ve eylemlerini meşrulaştıran militarist diskurların sosyal eğitim yoluyla nasıl yeniden üretildiklerine ve yaygınlaştırıldıklarına yeterli ilgi göstermemiştir. Bu çalışma, militarist diskurların eğitimde nasıl yankılandığını, 1950-2012 yılları arasında okutulmuş 16 adet ortaokul (8. sınıf) vatandaşlık ve sosyal bilgiler ders kitabının kritik söylem analizini yaparak göstermeyi amaçlamaktadır. Araştırmanın bulgularına göre, militarist diskurlar, 1950'den itibaren değişen yoğunlukta ders kitaplarında yer bulmuş ve 28 Şubat 1997 askeri müdahalesi sonrası zirve yapmıştır. Ders kitaplarında tespit edilen militarist diskurlar ordunun devlet sistemi içerisindeki politik otonomisini ve demokratik sistemin işleyişine zarar veren veya onu kesintiye uğratan müdahalelerini normalize etmiş, doğallaştırmış ve hatta yüceltmiştir. Türkiye'nin Avrupa Birliği (AB) üyeliği için adaylık statüsü aldığı 1999 Helsinki Zirvesi sonrası azalmaya başlayan militarist diskurlar, 2010'lu yıllarda büyük ölçüde ders kitaplarından kaybolmuştur. Ders kitaplarının militarist diskurlardan temizlenmesinde AB üyelik reformlarının çok belirgin bir rol oynadığını ileri süren mevcut çalışma, militarist diskurların eğitimde tekrar yankılanmasını önlemeye ve Türkiye'de sosyal eğitimin demokratikleşmesine katkılar sunabilir.
\end{abstract}

Anahtar Kelimeler: Vatandaşlık eğitimi, sosyal bilgiler eğitimi, darbeler, militarizm, ders kitapları

\begin{abstract}
The Turkish military, one of the significant actors in Turkey's nationalisation and modernisation history, has had a dominant position within the Turkey's state system. Its political autonomy in the state system and its interventions in politics have not complied with the norms and principles of democracy. By using public discourse production means like education, the military has attempted to normalise and legitimise its anti-democratic status and behaviours that constitute an anomaly according to democratic norms. Existing studies have not paid sufficient attention to ways in which the discourses legitimising the military's anti-democratic status and behaviours were re-produced via social education. The present research aims to illustrate how militarist discourses were resonated in education by providing a critical discourse analysis of 16 middle school $\left(8^{\text {th }}\right.$ grade) citizenship and social studies textbooks, which were taught from 1950 to 2012. Findings revealed that, from the 1950s, the militarist discourses had found their expressions in the textbooks with varying degree of intensity and culminated in the post-1997 coup years. The militarist discourses in the textbooks normalised, legitimised and even glorified the anti-democratic political autonomy of the military within the state system and the military's interventions in politics that either disrupted or harmed the functioning of Turkey's democratic order. After the European Union (EU) recognised Turkey as a candidate state for membership in the 1999 Helsinki Summit, the militarist discourses in the textbooks began to dissipate and eventually disappeared to a great extent in the 2010s. The present study, which puts forward that the EU membership reforms played a decisive role in clearing

\footnotetext{
* Bu çalışmanın bir kısmı, Çanakkale 18 Mart Üniversitesi’nde, 30 Ekim-1 Kasım 2018 tarihinde düzenlenen 2. Uluslararası Sosyal Bilimler Eğitimi Sempozyumu'nda bildiri olarak sunulmuştur.

** Dr., Amasya Üniversitesi, Eğitim Fakültesi, Sosyal Bilgiler Öğretmenliği Anabilim Dalı, Amasya-Türkiye, ORCID: 0000-0002-1869-312X, e-posta: akerimsen@gmail.com
} 
the textbooks from the militarist discourses, can contribute to the prevention of a possible come-back of militarist discourses in education and the democratisation of social education in Turkey.

Keywords: Citizenship education, social studies education, coups, militarism, textbooks

\section{Giriş}

Türkiye modernleşmesinin en önemli aktörlerinden birisi olan ordunun devlet sistemi içerisindeki hâkim konumu ve müdahil eylemleri yerleşik demokrasi norm ve ilkeleriyle bağdaşmayan bir görünüm sergilemiştir (Cizre, 2011; Cizre-Sakallığlu ve Çınar, 2003; Hale, 2003; Jenkins, 2007). Gerek liberal gerekse cumhuriyetçi demokrasilerin en ayırt edici vasıflarından birisi, ordunun seçilmiş meşru hükumetlerin sivil anayasal kontrolüne tabi olmasıdır. Özellikle cumhuriyetçi demokrasilerde, ülkenin bağımsızlığını ve rejimin varlığını sürdürebilmesi ile zorunlu askerlik arasında doğrudan bir bağlantı olduğu için, ordu hayati bir kurum olarak konumlandırılmıştır (Burk, 2000, 2002). Buna rağmen, ordu her zaman, demokratik meşruiyete sahip, parlamento ve bakanlar kurulu gibi sivil kurumların anayasal kontrolüne tabi olmuştur. $\mathrm{Bu}$ yerleşik normatif ilkeye rağmen, Türkiye'de ordu seçilmiş iradenin üzerinde bir yerde konumlanmış, politik sistem üzeri bir rol ile sistem kurucusu ve düzenleyicisi gibi davranmıştır. Ordu, demokrasi teori ve pratiklerine göre bir anomali teşkil eden bu konum ve eylemlerini, eğitim gibi kamusal diskur üretme araçlarını kullanarak olumlama, doğallaştırma ve normalleştirme yoluna gitmiştir.

Türkiye'de ordu ve eğitim arasındaki ilişkiyi inceleyen çalışmalar özellikle iki konuya yoğunlaşmıştır. Çalışmaların bir kısmı, ordunun eğitim yoluyla belirli bir resmi milliyetçilik ideolojisini nasıl yaydığını, bu ideolojinin müfredatta nasıl yankılandığını ve zaman içerisinde nasıl bir değişim gösterdiğini incelemiş̧tir (Kaplan, 2002, 2005, 2006; Ozgur, 2012; Özdalga, 1999; Sen ve Starkey, 2017; Yavuz, 1999). Çalışmaların diğer kısmı ise, "ordu ve askerliğe dair değerlerin, pratiklerin, süreçlerin ve yaklaşımların" eğitim yoluyla nasıl gündelik hayata yayıldığ ve doğal kabul edildiklerini göstermeyi amaçlamıştır (Altınay, 2009, s. 144). İkinci gruptaki çalışmalar, Türklerin asker-millet oldukları gibi militarizmle ilişkili diskurların, nereden gelip ders kitaplarına nasıl girdiğini ve nasıl olgusal bir kabule dönüştüklerini göstermeye çalışmıştır. $\mathrm{Bu}$ çalışmalar, militarist, şiddeti normalleştiren, cinsiyetçi ve dışlayıcı söylemlerin müfredatta yer almasını modern demokrasi ve insan hakları değerleriyle çatıştığını not etmiştir (Altınay, 2004; Kancı ve Altınay, 2007; Sen, 2018). Fakat her iki gruptaki çalışmalar da ordunun siyaset-üzeri, demokrasi-dışı, koruyucu ve kollayıcı bir yere kendisini konumlandırmasını ve bu pozisyondan anti-demokratik eylemlerde bulunmasını normalize eden ve hatta yücelten diskurların müfredatta nasıl yankılandığını ve zaman içinde nasıl değiştiğini incelememiştir.

$\mathrm{Bu}$ çalışma, tarif edilen militarist diskurların ders kitaplarında hangi stratejilerle doğal, normal ve meşru bir hale getirildiğini ve nasıl yeniden üretilip ve güçlendirildiğini göstermeyi amaçlamaktadır. Bu amaçla, 1950-2012 yılları arasında okutulan 16 adet 8. sınıf vatandaşlık ve sosyal bilgiler ders kitaplarındaki militarist diskurlar tespit ve analiz edilerek, vesayetçi sistem olarak nitelenen ordu hegemonyasının müfredata etkilerinin önemli bir boyutuna ış1k tutulacaktır. Sosyal eğitim (tarih, vatandaşlık, coğrafya, sosyal bilgiler dersleri) yoluyla militarist ve antidemokratik diskurların nasıl yeniden üretildiğini göstermek, Türkiye eğitim sisteminin demokratikleşmesi ve eğitim yoluyla demokrasi kültürünün gelişmesi açısından oldukça önemlidir. Bu açıdan, mevcut çalışmanın bulguları, sosyal eğitim araştırmacıları ve öğretmenleri ve gelecek müfredat reformları için faydalı olabilir.

\section{Teorik Çerçeve: Ordu ve Eğitim}

Türkiye'de batılılaşma çabalarının başladığı ilk kurum olan ordu, sonraki yıllarda Türkiye modernleşmesinin öncü kurumu olmuştur (Berkes, 1998; Lewis, 2002). Osmanlı'da, 18. Yüzyıl sonlarına doğru savaşlardaki yenilgileri ve toprak kayıplarını durdurabilmek amacıyla kurulan modern askeri okullar, daha sonraki dönemlerde Türkiye modernleşmesini yöneten askerleri yetiştirmiştir (Karaosmanoğlu, 2000; Zürcher, 2005). Türkiye Cumhuriyeti'nin kurucu kadrosunda askerlerin ezici çoğunlukta olması, modernleşme ve ulus inşası süreçlerini askerlerin yönetmesi, 1989'da Turgut Özal cumhurbaşkanı seçilinceye kadar Celal Bayar hariç tüm 
cumhurbaşkanlarının asker kökenli olması, Türkiye'de asker sınıfının ne denli etkin olduğuna işaret etmektedir. İdeolojik bir devlet aygıtı olarak ordu, bu etkinliği sayesinde Türkiye'nin resmî ideolojisi olarak nitelenen seküler milliyetçilik (Kemalizm ve 1980 sonrası Atatürkçülük) ideolojisini sürdürme rolünü de üstlenmiştir (Özyürek, 2006).

İdeolojiler, bir grup, kurum veya sınıfla ilişkili sosyal inançlar bütünü olarak tanımlanabilirler (van Dijk, 1998). İdeolojiler, söz konusu gruba kimin üye olabileceğini, o grubun tipik aktivitelerini, genel hedeflerini, o grubun norm ve değerlerini, diğer gruplarla ilişkilerini ve kendi grup kaynaklarını kimlerle paylaşacaklarını belirleyen diskurların bütünüdür. Türkiye'de ordunun kendi kurumsal alanı içerisinde üretilen ve kendi ayrıcalıklarını sürdürmeyi amaçlayan diskurların bütünü militarist ideolojiyi oluşturmaktadır. Bu ideoloji, Türk Silahlı Kuvvetlerinin (TSK) Türkiye demokrasisi içerisinde politik bir otonomiye sahip olmasını ve bu hâkim pozisyondan politikaya müdahalelerini meşrulaştırır ve hatta yüceltir.

TSK'nın kendi içişleriyle (özlük işleri, promosyon, askeri modernizasyon gibi) ilgili kararları verebilmesini ifade eden kurumsal otonomisi demokrasi normları ile çelişmemesine rağmen, TSK'nın devlet sistemi içerisinde bir yere bağlı olmaması şeklinde özetlenebilecek politik otonomisi demokrasi normlarına göre bir anomaliyi teşkil etmektedir (Celep, 2014; Karaosmanoğlu, 2000). TSK, üçüncü dünya ülkelerinin birçoğunda olduğu gibi, kendi görev alanını sadece dış düşmanlara karşı yurdu savunma ile sınırlamamış, iç düşman veya iç tehdit kavramını geliştirerek ülke içerisinde politik roller alagelmiştir. 1980 öncesi dönemde komünizm ile 1980 sonrası ve özellikle 1990'larda iç tehdit unsurları olarak nitelediği PKK terörü ve politik İslamcılıkla mücadele etmiştir. Kendisini milli çıkarların koruyucusu olarak konumlandıran TSK, politik bir aktör olarak davranmış, milli güvenlik siyasetinin belirlenmesinde kilit rol oynamış ve askeri müdahale yapma imkânını elinde bulundurmuştur (Cizre-Sakallığlu, 1997; Jenkins, 2007). Bu sayede, 27 Mayıs 1960 ve 12 Eylül 1980'de doğrudan darbe yoluyla hükumetleri görevden uzaklaştırmış ve sonrasında yeni anayasalar hazırlatarak kışlasına dönmüş; 12 Mart 1971 ve 28 Şubat 1997 yıllarında, dolaylı müdahalelerle iktidarların el değiştirmesini sağlamıştır. TSK, üçüncü dünya ülkelerindeki örneklerden farklı olarak, askeri darbeler sonrası yönetimi sivillere devrederek kendi alanına çekilmesine rağmen, kendi kontrolünde hazırlattığı anayasa ve yasalar aracılığıyla ayrıcalıklı konumunu ve politik otonomisini sürdürmeye özen göstermiştir.

Ordu'nun politikadaki bu etkin rolü, 1982 Anayasası'nın orduya sağladığı anayasal özerklik, önemli devlet kurumlarında temsilci bulundurma ve önemli karar vericiler üzerinde enformel etki gücünü elinde bulundurma imkanları ile zenginleşmiştir (Jenkins, 2007). TSK'nın sivil otoritelerin anayasal kontrolü dışında hareket etme imkân ve kabiliyeti Milli Güvenlik Kurulu'nun (MGK) 1982 Anayasası ile artırılan yetkileriyle pekişmiştir. MGK'nın sekretarya işlerini yapmakla görevli MGK Genel Sekreterliği, 400'den fazla ezici çoğunluğu asker olan çalışanı ile çeşitli politikalar ile ilgili belgeler hazırlayarak MGK toplantılarının gündemini belirleme gücünü elinde bulundurmuştur. MGK Genel Sekreterliği, milli güvenliğe ilişkin belgeler hazırlayarak MGK'ya altyapı hizmeti sunduğu için, sivil otoritelerdeki bilgi ve belgelere sınırsız erişim imkânına sahip olmuştur. Böylece, TSK, MGK kanalıyla sivil hükumeti etkileme ve kontrol etme şansına sahip olmuştur. Ayrıca, birçok sivil otorite kurulunun asker üyeleri olagelmiştir. Örneğin, Yüksek Öğretim Kurulu, Radyo Televizyon Üst Kurulu, Milli Güvenlik Mahkemeleri gibi devlet birimlerinde asker üyeler yer almıştır.

TSK'nın sistem içerisindeki politik otonomisini sınırlandırmaya dönük radikal hamleler, 1999 Helsinki Zirvesi'nde Türkiye'nin Avrupa Birliği (AB) için üye ülke statüsü elde etmesinden sonra atılmıştır (Cizre-Sakallığlu, 2003; Hale, 2003). Bu bakımdan, 1950'de Demokrat Parti'nin (DP) iktidara gelmesinden 1999 Helsinki Zirvesi'ne kadarki dönem asker-kontrollü demokrasi dönemi olarak nitelendirilebilir. $\mathrm{Bu}$ dönemi ordunun sivil siyasete müdahil eylemleri ve hükumetleri kontrol etmeye dönük hamleleri karakterize etmektedir. 1999 sonrası dönemde, ordunun politik otonomisini sınırlandırmaya yönelik yasal değişiklikler, ordu çevrelerinden büyük tepki toplamıştır. Ordunun $\mathrm{AB}$ reformlarına direnç göstermesini eleştiren Başbakan Mesut Y1lmaz, ordu çevrelerinin, Türkiye'de bir milli güvenlik sendromu yarattığını ileri sürmüştür. Ordunun direncine rağmen, AB uyum yasaları kapsamında, 1999 yılında devlet güvenlik mahkemelerindeki askeri hâkimlerin görevine son verilmiş, 2001 'de MGK'nın üye dağılımında 
sivil üyelerin sayısı artırılmıș ve Bakanlar Kurulu'na MGK kararlarına öncelik verme değil, bu kararları değerlendirme hakk1 verilmiştir. 2002 yılında yeni bir hükumetin göreve gelmesinden sonra ordunun politik otonomisini sınırlandırma hamleleri yoğunluk kazanmıştır. 2003'te MGK Genel Sekreteri'nin asker kökenli olması gerekliliği ve MGK Genel Sekreterliği'nin sivil otoritelerdeki bilgi ve belgelere sınırsız erişim imkânı kaldırılmıştır (Jenkins, 2007). Ayrıca MGK Genel Sekreterliği atama yönetmeliğinde yapılan değişiklikle bu önemli devlet biriminde sivillerin oranı artırılmıştır. MGK toplantılarının düzenlenme sıklığı ayda birden, iki ayda bire indirilerek, ordunun hükümetle temas sıklığ 1 azaltılmıştır.

$\mathrm{AB}$ uyum yasaları çerçevesinde ordunun politik otonomisine önemli sınırlamalar getirilmesine rağmen, orduya anayasal otonomi veren anayasa maddesi hala yürürlüktedir (TBMM, 1982, T.C. Anayasa, Madde 117). Ayrıca ordunun eğitime kendi ideolojik diskurlarını sokmasına müsaade eden milli eğitimin yasal çerçevesi ve yönetimsel yapısında da köklü yapısal değişiklikler olmamıştır. Ordu etkisinin yoğun hissedildiği bir politik kontekstin ürünü olan 1739 sayılı MEB Temel yasası hala yürürlüktedir. Müfredat otoritesi olan Talim Terbiye Kurulu Başkanlığı üyelerini atama biçimi ve bu devlet biriminde öğretim programlarını hazırlama teamülleri hala anti-demokratik müdahaleleri mümkün k1lacak bir görünüm arz etmektedir. Dolayısıyla, TSK'nın kendi kurumsal alanı içerisinde ürettiği militarist ideoloji ile ilgili diskurların, eğitimde yankılanması [re-contextualization] hala mümkün gözükmektedir (Bernstein, 2003). TSK'nın devam eden hâkim statüsü, eğitimin yasal çerçevesi ve müfredat otoritesinin idari yapısı devletin bu iki kurumu (TSK ve MEB) arasındaki diskur etkileşimini oldukça kolaylaştırmaktadır. Bu faktörler, TSK'nın kurumsal alanında üretilen ideolojik diskurların eğitim alanına akabilmesine ve bu diskurların ulusal müfredat yoluyla tüm öğretmen ve öğrencilere ulaşabilmesine olanak sağlamaktadır.

\section{Yöntem}

$\mathrm{Bu}$ çalışma, ders kitabı analizine dayanan nitel bir eğitim araştırmasıdır (Merriam, 2009). Tanımlanan militarist ideolojiyle ilişkili diskurlardaki devamlılık ve değişiklikleri tespit etmek için, demokrasi teori ve pratiklerinin çok yaygınlık kazanmadığı tek parti iktidarı dönemine (1923-1950) değil, parlamenter demokrasinin ihdas edilmesinin en somut kilometre taşı olan DP'nin 1950'de iktidara gelmesinden sonraki döneme yoğunlaşılmıştır. 1950'den vatandaşlık derslerinin kaldırıldığ 2012 'ye kadarki dönemde militarist diskurlardaki değişiklik ve devamlılıklar vatandaşlık ve sosyal bilgiler ders kitapları incelenerek tespit ve analiz edilmiştir.

\section{Örneklem ve veri toplama}

Türkiye Cumhuriyeti tarihi boyunca vatandaşlık dersleri en uzun süre ortaokul son sınıflarda okutulduğu ve vatandaşlık derslerinde en az kesinti bu sınıf seviyesinde olduğu için, militarist diskurlardaki değişiklik ve devamlılıkları daha iyi takip edebilmek amacıyla, ortaokul son sınıf ders kitapları örneklem olarak seçilmiştir. Ayrıca ortaokul sosyal eğitim ders kitaplarının ön incelemesi sonrası, militarist diskurlar en yoğunluklu olarak bu seviyedeki ders kitaplarında tespit edilmiştir. Sadece orta son sınıf vatandaşlık derslerine yoğunlaşmanın diğer bir nedeni ise, kritik diskur analizi yönteminin derinlikli analiz gerektirmesi sebebiyle veri hacmini sinırl tutma gerekliliğidir. Son olarak, demokrasiye dair teori ve pratiklerin yoğunluklu olarak öğretildiği ders vatandaşlık dersi olduğu için bu alandaki ders kitapları kullanılmıştır.

1950-2012 yılları arasında okutulan 8. sınıf vatandaşlık derslerinin, vatandaşlık dersi okutulmadığ 1 dönemler için sosyal bilgiler derslerinin her birisine ait, Milli Kütüphane'deki mevcut ders kitaplarından ikişer adet seçilmiştir. En çok baskısı olan ders kitapları, darbe öncesi ve darbe sonrası versiyonlarının mevcut olması gibi kriterler 1şığında bu çalışmaya dâhil edilmiştir. En çok baskısı mevcut olan ders kitapları, yıllar içerisinde bir değişim olup olmadığını tespit etmek için daha elverişli oldukları ve ülke genelinde daha yaygın kullanılmış olabilecekleri gerekçesi ile seçilmiştir. Ders kitapları arasında olabilecek farklılıklara karşı çalışmayı daha duyarlı hale getirmek için her bir derse ait bir değil, iki ders kitabı incelenmiştir. Vatandaşlık derslerinin kaldırıldığı yıllarda (1968-1985 arası), vatandaşlık konularının sosyal bilgiler derslerine entegre edilmesi nedeniyle 8. sınıf sosyal bilgiler ders kitapları çalışmaya dahil 
edilmiştir. Böylece, çalışma kapsamında, 1950'den 4+4+4 eğitim reformu ile vatandaşlık eğitiminin kaldırıldığ 2012 yılına kadar kullanılan 16 adet ortaokul son sınıf vatandaşlık ve sosyal bilgiler ders kitabı analiz edilmiştir (MEB, 2012). Tablo 1 incelenen ders kitaplarının künye bilgilerini göstermektedir:

Tablo 1

İncelenen Ders Kitaplarının Künye Bilgileri

\begin{tabular}{|c|c|c|}
\hline Ders Ad 1 & Ders Kitab1 Künyesi & $\begin{array}{l}\text { Karş1laştırma için } \\
\text { Kullanılan Bask1 }\end{array}$ \\
\hline $\begin{array}{l}\text { Yurttaşlık Bilgisi III } \\
(1948-1968)\end{array}$ & $\begin{array}{ll}\text { - } & \text { Aksan, H. (1958). Yurttaşlık } \\
& \text { bilgisi III. İstanbul: Ders } \\
& \text { Kitapları Türk Ltd. Şti. } \\
\text { - } & \text { Şerbetçioğlu, F. ve Tülin, H. } \\
& \text { (1958). Yurttaşllk bilgisi III. } \\
& \text { Ankara: Maarif Basımevi. }\end{array}$ & $\begin{array}{ll}\text { - } & \text { Aksan, H. (1963). Yurttaşlık } \\
\text { bilgisi III. İstanbul: Ders } \\
\text { Kitapları Anonim Şirketi. } \\
\text { - Şerbetçioğlu, F. ve Tülin, H. } \\
\text { (1962). Yurttaşlık bilgisi III. } \\
\text { Ankara: Milli Eğitim } \\
\text { Basımevi. }\end{array}$ \\
\hline $\begin{array}{l}\text { Sosyal Bilgiler III } \\
(1968-1985)\end{array}$ & $\begin{array}{l}\text { Akşit, N. ve Sanır, F. (1973). } \\
\text { Sosyal bilgiler III. İstanbul: } \\
\text { Ders Kitapları Anonim } \\
\text { Şirketi. } \\
\text { Asal, T., Akşit, N. ve Sanır, F. } \\
\text { (1975). Sosyal bilgiler III. } \\
\text { Ankara: Türk Tarih Kurumu } \\
\text { Basımevi. }\end{array}$ & $\begin{array}{l}\text { Asal, T., Akşit, N. ve Sanır, } \\
\text { F. (1984). Sosyal bilgiler III } \\
\text { (9. bs). İstanbul: Milli } \\
\text { Eğitim Basımevi. }\end{array}$ \\
\hline $\begin{array}{l}\text { Vatandaşlık Bilgileri } \\
\text { III (1985-1995) }\end{array}$ & $\begin{array}{l}\text { Dal, K., Çakıroğlu, O. ve } \\
\text { Özyazgan, A. İ. (1986). } \\
\text { Vatandaşlık bilgileri III (2. } \\
\text { bs). Ankara: Milli Eğitim } \\
\text { Basımevi. }\end{array}$ & $\begin{array}{l}\text { - Dal, K., Çakıroğlu, O. ve } \\
\text { Özyazgan, A. İ. (1994). } \\
\text { Vatandaş̧lı bilgileri III (10. } \\
\text { bs). İstanbul: Milli Eğitim } \\
\text { Basımevi. }\end{array}$ \\
\hline $\begin{array}{l}\text { Vatandaşl1k ve İnsan } \\
\text { Hakları Eğitimi } 8 \\
\text { (1995-1999) }\end{array}$ & $\begin{array}{l}\text { - Tanır, A. (1997). Vatandaşlık } \\
\text { ve insan hakları eğitimi 8. } \\
\text { Ankara: Özgün Matbaacılik. } \\
\text { - Yiğit, U. ve Turan, T. (1996). } \\
\text { Vatandaşlı ve insan hakları } \\
\text { eğitimi 8. İstanbul: Bu } \\
\text { Yayınevi. }\end{array}$ & \\
\hline $\begin{array}{l}\text { Vatandaşlık ve İnsan } \\
\text { Hakları Eğitimi } 8 \\
(1999-2005)\end{array}$ & $\begin{array}{l}\text { Çiftçi, F., Yüksel, İ., Yıldız, } \\
\text { R., Kıvrak, M., Öztürk, R., } \\
\text { Cereno, A. ve Efe, F. (1999). } \\
\text { Vatandaşlı ve insan hakları } \\
\text { eğitimi ders kitabı } 8 \text { (1. bs). } \\
\text { Ankara: MEB Devlet } \\
\text { Kitapları. } \\
\text { Yiğit, U. (2007). Vatandaşlık } \\
\text { ve insan hakları eğitimi ders } \\
\text { kitabı 8. İstanbul: Batu. }\end{array}$ & $\begin{array}{l}\text { Çiftçi, F., Yüksel, İ., Yıldız, } \\
\text { R., Kıvrak, M., Öztürk, R., } \\
\text { Cereno, A. ve Efe, F. } \\
\text { (2004). Vatandaşlık ve insan } \\
\text { hakları eğitimi ders kitabı } 8 \\
\text { (1. bs). Ankara: MEB } \\
\text { Devlet Kitapları. }\end{array}$ \\
\hline
\end{tabular}




\begin{tabular}{lll}
\hline & $\bullet$ & Özpolat, V. (Ed.). (2012). \\
& Vatandaşlık ve demokrasi \\
& eğitimi: Ders kitabi 8 (2. bs). \\
Vatandaşlık ve & Ankara: MEB. \\
Demokrasi Eğitimi 8 & Aşan, E. (2014). Vatandaşlık \\
$(2010-2012)$ & ve demokrasi eğitimi dersi 8. \\
& Ankara: Ekoyay. \\
\hline
\end{tabular}

\section{Verilerin analizi}

Veri analizinin ilk aşamasında, militarist ideoloji olarak tarif edilen ordunun anti-demokratik konum ve eylemlerinden söz eden bölümler ders kitaplarında tespit edilmiş ve bu bölümler ayrı bir belgeye kaydedilmiştir. İkinci aşamada, not edilen bölümler aynı ders kitabının farklı baskılarında yer almış mı yoksa çıkarılmış veya değiştirilmiş mi tespit etmek amacıyla ders kitapları karşılaştırmalı olarak incelenmiştir. Darbe sonraları militarist ideolojinin etkisi yoğunlaştı̆̆ı için, ders kitaplarındaki darbe sonrası yapılan değişiklikler özellikle tespit edilmeye çalışılmıştır. Militarist diskurlar, en net biçimiyle, ders kitaplarının darbe öncesi ve sonrası versiyonlarının karşılaştırmalı incelemesi sonucu ortaya çıkarılmışıı. Ders kitaplarının darbe öncesi versiyonlarında yer alan örtük militarist diskurların, darbe sonrası revize edilen ders kitaplarında belirginleştirildiği, detaylandırıldığı ve vurgulandığı tespit edilmiştir. Veri analizinin son aşamasında, tespit edilen bölümlerin her birisi kritik söylem analizi teamülleri takip edilerek çözümlenmiştir.

Kritik söylem analizi disiplini hâkim sosyal yapı ve grupların veya daha genel ifadeyle gücü elinde tutan aktörlerin ayrıcalıklı pozisyonlarını diskur aracılığıyla nasıl sürdürdüklerini göstererek sosyal adaletin gelişmesine katkı sunmayı amaçlar. Bu çalışmada, kritik diskur analizinin farklı versiyonları içerisinden van Dijk (1998), Fairclough (2010) ve Van Leeuwen (2007)'nin geliştirdiği analiz araçları ve kavramsal çerçeveden yararlanılmıştır. İdeolojik diskurların, biz-onlar, grup içi-grup dışı karşıtlığı ile şekillendikleri, ait oldukları sosyal grubun veya kurumun pozitif özelliklerini vurgulayıp negatif özelliklerini geri plana attıkları veya gizledikleri; düşman veya rakip saydıkları grupların ise negatif özelliklerini vurgulayıp pozitif özelliklerini arka plana attıkları veya gizledikleri kabulüyle metindeki diskurlar tespit edilmiş ve çözümlenmiştir. Ayrıca, cümle yapıları, metindeki anlamsal ilişkiler, başka bağlama ait diskurların pedagojik bağlama oturtulma biçimleri [recontextualization], kelime tercihleri, çok seslilik [diolagicality] yaratma stratejileri, rasyonalize etme ve meşrulaştırma biçimleri, faili gizleme, aktörü ön plana çıkarma, varsayımlar ve değer ifadeleri gibi hususlara dikkat edilmiştir. $\mathrm{Bu}$ diskur stratejileri vasıtasıyla, ders kitaplarındaki militarist diskurların, ordunun pozitif temsilini nasıl yaptıkları ve ordunun politik otonomisi, demokrasi-üzeri konum ve eylemlerini nasıl normalize ettikleri ve meşrulaştırdıkları ortaya çıkarılmıştır. Analiz edilen bölümler içerisinden, ders kitaplarında vurgulanan militarist diskuru en tipik olarak yansıttığ 1 düşünülen kısımlar alıntılanmıştır. İncelenen her bir derse ait ders kitaplarının, şayet mevcut ise, her ikisinden de alıntı yapılmaya özen gösterilmiştir.

\section{Bulgular}

Bulguların sunumu, ders özelinde kronolojik bir sırayı takip etmektedir.

Yurttaşlık bilgisi dersi (1950-1968): Tarif edilen militarist diskur, Yurt Bilgisi 3 ders kitabında şu ifadelerle yer almıştır:

Bugün de sinırlarımızda, güzel denizlerimizde, mavi göklerimizde, bizi, yurdu, Cumhuriyetimizi koruyan hep odur. Türk ordusu, Türk milletinin öz evladl, silahlı kollarldır. 
Devletimiz, yurdumuzu, istiklalimizi ve Cumhuriyetimizi korumak vazifesini kahraman ordumuz vasıtaslyla sağlar ve başarır. Milletimizin ordumuza güveni büyüktür (Şerbetçioğlu ve Tülin, 1958, s. 75).

Alıntıya hâkim diskura göre Türk milletinin bağımsızlığını koruması, varlığını sürdürmesi, Cumhuriyet rejiminin devam etmesi hep "kahraman bir ordumuz" sayesindedir. Ordu'nun bağımsızlığı sürdürme ile ilişkilendirilmesi demokrasi normlarıyla çelişmeyebilir fakat "Cumhuriyet"in bir yönetim biçimi, bir devlet rejimi olduğunu düşünüldüğünde, cumhuriyet rejiminin devamının güçlü bir ordunun varlığı ile açıklanması bir anomali teşkil etmektedir. Cumhuriyet rejiminin korunmasında ve sürdürülmesinde, kamusal konularla ilgilenen ve yönetim süreçlerine katılan demokrat vatandaşların önemini vurgulamak, yerleşik demokrasi normlarına göre daha uygun olabilirdi. Bu açıdan değerlendirildiğinde, alıntılanan üç cümlede, ordu iki kez Cumhuriyet rejiminin bekçisi olarak resmedilmektedir. Bağımsızlığı koruma ve yurt savunması gibi ordunun asli görevlerinin yanına eklenen cumhuriyet rejimini korumak ordunun asli bir görevi gibi sunulmaktadır. Alıntının ilk cümlesinde orduya "hep odur" yüklemi ile atıf yapılarak canlı bir özne gibi sunulmakta ve ordu rejimin ve bağımsızlı̆̆ın yegâne güvencesi olarak yüceltilmektedir. Takip eden cümle, "Türk milleti" ve "Türk ordusu" arasında aile metaforu üzerinden organik bir bağ tesis etmektedir: "Türk ordusu, Türk milletinin öz evladı, silahlı kollarıdır". Bu cümlede, ordu, Türk milletinin evladına ve bir bedenin (Türk milletinin) kollarına benzetilerek, ordu ve millet arasında organik bir bütünlük olduğu ifade edilmektedir. Bu organik bağ sadece ordu için kurulmakta millet ve ordu arasındakine benzer bir organik bağ, millet ve parlamento veya diğer demokratik kurumlar için kurulmamaktadır. Türk milletinin "öz evladı, silahlı kolları" şeklinde nitelenen ordudan daha önemli, daha hayati başka bir kurumdan bahsedilmemektedir. Bu militarist diskurun vurguladığı ordunun hâkim konumu ve hayatiliği, iç ve dış tehditlere atıflarla iyice pekiştirilmektedir:

Bugünün savaşları artık eskisi gibi sinır boylarında olmuyor. Düşmanlar, ordular arkadan savaşa katılmayan sivil halk arasından vurmaya çalışıorlar. Köylere, şehirlere havadan asker indiriyorlar. Gizli çalışan adamlartyla içerde bozgun yapmaya çalışıyorlar. Ordular cephede dövüşürken, sivil halkın kadınlı erkekli bu zararlı varlıklarla çarpışması memleket borcu oluyor (Şerbetçioğlu ve Tülin, 1958, s. 76).

Bazı devletler akla gelmedik hilelere başvurarak, bağımsız memleketleri içinden yıkmağa çalışmaktadırlar. İstiklal ve hürriyetlerini ellerinden kaptırmak istemeyen milletler, dünyanın bu emniyetsiz durumu karşısında, silahlamağa ve kudretli bir ordu bulundurmağa gayret sarf etmekte haklıdirlar (Aksan, 1958, ss. 75-76).

Bu alıntılarda, savaşların vuku bulma biçiminin değişmesi nedeniyle artık orduların daha da önemli hale geldiği görüşü rasyonel bir temele oturtulmak istenmektedir. Alıntılardaki bu hâkim diskur, daha sonraki yıllarda çok belirgin bir biçimde vurgulanacak olan iç tehdit ve iç düşmana yönelik diskurun formasyon sürecinin erken bir evresini temsil etmektedir. Burada, iç tehdit ve iç düşmanlar, cephe arkasına sızan ("havadan asker indiriyorlar") ve cephe arkasından orduya saldıran yabancılar olarak resmedilmektedir. Bu diskur, ülke içerisinde yaşayan halkın bir bölümünü iç tehdit-iç düşman olarak ima etmemektedir. Yerli halkın içeriye sızan ajanların ("gizli çalışan adamlarıyla") oyunlarına alet olabileceğini ve halkın bu konuda bilinçli olması gerektiğinin altı çizilmektedir. Bu diskur ilerleyen yıllarda başkalaşarak, militarist ideolojinin önemli bir unsuru haline gelecektir. Ayrıca, alıntılanan bölümde, savaşların vuku bulma şeklinin değiştiğinin, cephe kavramının artık tüm yurt olduğunun ve halkın tamamının yurt savunmasına katkıda bulunması gerektiğinin vurgulanması, tüm vatandaşların ordunun bir parçası gibi değerlendirildiğini göstermektedir.

Darbe öncesi döneme ait bir ders kitabındaki bir görsel, buraya kadar ayrıntıları verilen militarist diskuru daha görünür kılmaktadır. Bir tank üzerinde iki askerden birisinin bir Türk bayrağı dalgalandırdığını gösteren resmin altında "Kahraman askerlerimizle birlikte geçen 
bayrağımızı gördüğümüz zaman durmak, onu saygıyla selamlamak hepimizin vazifesidir" ifadesi yer almaktadır (Şerbetçioğlu ve Tülin, 1958, s. 77). Bu görselde, bağımsızlığın sembolü bayrağı tutan bir asker ve bu askeri taşıyan araç ise bir tanktır. Görseldeki bu iki ana unsur orduyu temsil etmektedir, bu nedenle bayrağa selam durmayı telkin eden bu resim, bayrak aracilığıyla tüm vatandaşların orduya ve ordu mensuplarına karşı saygılı olmasını telkin etmektedir. Örneğin, bir öğrencinin taşıdığı bir bayrak resmi ile bayrağa selam durmanın gerekliliği vurgulansa idi, mesaj çok daha farklı olabilirdi. Bayrağın bağımsızlığı temsil etmesi ve ordu ile ilişkili resmedilmesi daha derinlikli okunduğu vakit, bu görsel, bağımsızlı̆̆ın yegâne güvencesi olarak orduyu sunan hâkim militarist diskuru desteklemektedir.

Orduyu politika ve demokrasi üzeri bir kurum olarak sunan militarist diskurlar, buraya kadar alıntılanan ders kitaplarının darbe sonrası versiyonlarında çok daha belirgin hale gelmiştir. Örneğin, ders kitaplarına 1960 darbesi sonrası eklenen şu bölüm, iktidarların zamanı gelince "millet" tarafından cezalandırılabileceğinden bahsetmektedir:

Milleti aldatmanın hiçbir zaman cezasız kalamayacağını tarih bizlere göstermektedir. İktidara gelenlerin sözlerini tutması, açık kalpli, uyanık bulunması lazımdır. Devlet ve millet işlerini bir tarafa bırakıp, kendi yararlarına çalışmaları kadar kötü bir şey olamaz. İktidar partisinin bütün üyelerinin de bunu bilmeleri gerekir. Partilerine güvenerek yolsuz işler yapmaları, milletin büyüklerine karşı inancını sarsar. O millet inancı ki, şahlandiğı zamanlarda önüne geçilmez bir kuvvet olur. Tahtları devirir, iktidarı yıkar, tarihin akışını değiştirir. O milyonlarca inancın yarattı̆̆ yenilmez kuvvet gerektiği zamanlarda kendilerinden hesap da sorabilir (Şerbetçioğlu ve Tülin, 1962, s. 18).

$\mathrm{Bu}$ alıntıda, iktidardan hesap soran aktör olarak "...millet inanc1, ...bir kuvvet, ...yenilmez kuvvet" şeklinde üç özneye atıf yapılmaktadır. Bu üç özne herhangi bir kişiyi veya kurumu açıkça ifade etmemektedir. Ayrıca iktidar partilerine veya iktidardaki devlet yöneticilerine hesap sorma biçimi olarak "tahtları indirmek, iktidarı yıkmak, tarihin akışını değiştirmek, hesap sormak" gibi eylemler belirtilmektedir. Politik kontekstin parametrelerine bakarak, öznenin muğlak bırakıldığ 1 bu metindeki ana sosyal aktörü ordu olarak netleştirdiğimizde, belirtilen eylemler daha anlamlı gözükmektedir. Yani “...millet inanc1, ...bir kuvvet, ...yenilmez kuvvet" gibi özneler orduyu ima etmekte ve ordunun iktidar partilerine gerektiğinde "tahtları indirmek, iktidarı yıkmak, tarihin akışını değiştirmek, hesap sormak" gibi eylemlerle müdahalede bulunabileceği normal, meşru ve hatta gerekli bir durum olarak sunulmaktadır. Oysa yerleşik demokrasi normlarına göre iktidarı denetlemek, hukukun üstünlüğü prensibini temsil eden kurumlar ve seçimler vasıtasıyla mümkün olmaktadır. İktidarı denetleme mekanizmalarının hiçbirisine bir gönderme yapılmadan, ordu adeta iktidarın velisiymiş ve devletin emniyet supabıymış gibi resmedilmektedir.

Militarist diskurlar, 1960 darbesi sonrası ders kitaplarına eklenen "27 MAYIS DEVRIMI” başlıklı yeni ünitede çok daha net gözlenmektedir. Darbe sonrası ders kitapları, 27 Mayıs 1960’ı bir darbe değil bir "devrim” olarak sunarak, ordunun anti-demokratik eylemini yüceltmektedir:

Ĕgri yolda bulunan devlet adamları, gerçekleri milletten saklamak için dolambaçlı yollara, hile ve yalanlara başvurmak zorunda kalırlar. Bu oyalamalarla iktidarı bir müddet daha ellerinde tutsalar bile er-geç yıkılmağa ve yaptıklarının hesabını vermeğe mecbur kalırlar. Tarih bunun türlü örnekleriyle doludur (Aksan, 1963, s. 16).

Bir çıkmazda olduklarını gördükçe halkı yalanla, dolanla oyalamağa çalışıyorlar, devlet radyosunda yalan neşriyat yapmaktan çekinmiyorlardi. Ne pahasina olursa olsun iktidarda kalmak istiyorlard. Bu sebeple Seçim Kanununda değişiklik yaparak, halkın dilediği partiye oy vermesini güçleştirdiler. Seçim tarihini öne aldılar (...) Memlekette bir zulüm ve baskı idaresi bütün şiddetiyle sürerken gerek milletvekilleri gerek basın mensupları gerekse Türk aydınları memlekette hakiki demokrasinin nasıl kurulup 
gelişeceğini Türk Milletine anlatmaktan geri durmadılar. Hapishaneler gazeteciler ve aydın fikirlilerle doldu. Muhalefet milletvekillerine suikast yapıldı (Aksan, 1963, s. 36).

$\mathrm{Bu}$ alıntıda bir devr-i sabık yapılarak, DP iktidarının negatif tarafları vurgulanmaktadır. DP iktidarının negatif özelliklerinin vurgulanması ve ordunun pozitif özelliklerinin yüceltilmesi yoluyla bir darbe normalize edilmektedir. Tirmanan gerginlik ve artan siyasal şiddet olayları nedeniyle rejimin bekçisi, sistemin emniyet supabı olan ordunun duruma müdahil olması meşru ve gerekli bir eylem olarak sunulmaktadır. Darbe'yi devrim olarak sunan ünitede yer alan bu bölümler, orduya dair en ufak bir eleştiri içermemektedir. Ordu, biz, olarak yüceltilmekte, DP ise öteki-düşman olarak karalanmaktadır. Burada iktidarın el değiştirmesi, görevden uzaklaştırılmasına dair ana mekanizma olan seçimlere veya yargı kurumunun iktidarı denetleme pratiklerine bir gönderme yapılmadan iktidarın "er-geç yıkılma"sından ve "yaptıklarının hesabını verme"sinden bahsedilmektedir. Bu yıkılma eylemi ve hesap verme işlemi nasıl gerçekleşebilir konusu ile ilgili herhangi bir detay sunulmamaktadır:

Olayları ordu mensupları da dikkatle takip ediyorlardı. Ordumuzun şerefli bir mazisi vardı. Yurdumuzun içinde bulunduğu tehlikeli duruma ilgisiz kalamazdı. (...) 27 Mayıs devrimi bütün yurtta hakl bir hareket olarak kabul edildi ve sevinçle karşılandı (Şerbetçioğlu ve Tülin, 1962, s. 43).

27 Mayls Devrimi, alelade bir hükümet darbesi değildir. Bu ihtilal, Atatürk ruhu ile şahlanan Türk Gençliğinin, Türk Ordusunun ve Türk Milletinin, genç demokrasimizi yıkmak, Atatürk Devrimlerini yok etmek isteyen gerici zümreyi ezmesidir. Bu ihtilali yapmakla Türk milleti dünyadaki itibarını yeniden kazanmışıtır (...) Artık yurdumuzda, Atatürk'ün Erzurum ve Sivas kongrelerinde ortaya attı̆̆ (Egemenlik Ulusundur.) ülküsü gerçekleşmiş bulunmaktadır (Aksan, 1963, s. 39).

$\mathrm{Bu}$ alıntılarda, darbe yoluyla iktidar partisini görevden uzaklaştırmak yalnızca normalize edilmemekte aynı zamanda yüceltilmektedir. DP ve onu destekleyenlere, "gerici zümre", sahtekâr, baskıcı, otoriter gibi suçlayıcı ifadeler yöneltilmekte, darbe yapan ordu ise "şerefli bir mazisi" olan, "tehlikeli duruma ilgisiz" kalamayan, tüm Türk milletini temsil eden ve tüm halkın isteğini yerine getiren ve ulusal egemenlik ilkesini gerçekleştiren bir aktör olarak yüceltilmektedir. Böylece, ordu adeta üzerine düşen bir vazifeyi yerine getirmiş bir kurtarıcıymış gibi betimlenmektedir. Ordunun darbe yaparak hükumeti görevden uzaklaştırması ilginç bir şekilde ulusal egemenlik ilkesinin gereği olarak sunulmaktadır. Sanki darbe yapılmaksızın güvenliği sağlamanın başka hiçbir yolu yokmuş gibi bir mesaj verilmektedir. Militarist ideolojiyi destekleyen bu diskurlara ek olarak, alıntılanan her iki ders kitabının darbe öncesi versiyonlarındaki DP'yi temsil eden siyasetçilerin fotoğrafları, bu kitapların darbe sonrası versiyonlarından çıkarılmıştır. Ayrıca, DP'yi pozitif resmeden tüm ifadeler de çıkarılmıştır. Örneğin, "1950 yılında yapılan seçimlerle millet egemenliği tam olarak kurulmuş ve gerçek demokrasi devri başlamıştır" (Aksan, 1958, s. 28) ifadesi aynı ders kitabının darbe sonrası versiyonunda kaybolmuştur (Aksan, 1963).

Sosyal bilgiler dersleri (1968-1985): 1968 yılında yurttaşlık bilgisi dersleri, müfredata yeni konulan sosyal bilgiler derslerinin bir parçası olmuştur (Üstel, 2004). Bu dönemde, tarih, coğrafya ve vatandaşl1k dersleri ünitelerinin bir birleşimi şeklinde kurgulanan sosyal bilgiler dersi içerisinde ordunun anti-demokratik konum ve eylemlerini normalize eden diskurlar devam edegelmiştir. Fakat Yurttaşlık Bilgisi ders kitaplarının darbe sonrası versiyonları ile kıyaslandığında, ordunun pozitif resmini çizen diskurlarda önemli değişiklikler olduğu tespit edilmiştir. 1930'larda ders kitaplarına giren "Türkler Asker bir Millettir” miti devam edegelmiş (Altınay, 2004), fakat orduyu pozitif resmeden ifadeler şu şekilde modifiye edilmiştir:

Barış içinde yaşamak Türklerin en büyük isteğidir. (...) Hiçbir milletin topră̆ında gözümüz yoktur. Başka milletlerin de bizim vatanımızda emelleri olmasını istemiyoruz. 
(...) Biz milletimiz için yaşar, milletimiz için ölürüz. (...) Yaşamak ne kadar hakkımız ise askerlik yapmak da o kadar ödevimizdir (Akşit ve Sanır, 1973, s. 44).

Türkler her şeyden önce asker bir millettir. Bütün dünya onları böyle tanır. (...) Ordu bir okul gibidir. Orada askerler silahları kullanmayı ve savaş usullerini ögrenirler. Ayrıca kendilerine gerekli bilgiler ögretilir. ... Askerliğe başlarken ele avuca slğmayan, kaylt ve şarta gelemeyen ruhtaki insanlar ordudan ayrllırken akıllı, uslu, memleket için yararlı birer kimse olmuşlardır. (...) Türk ordusu, en yüksek okuldur. Öğrencisi de bütün Türk yurttaşlarıdır. Öğrettiği bilgi yurt sevgisi ve yurt savunmasıdır (Akşit ve Sanır, 1973, s. 46).

Alıntıların ilkinde, jenerik bir "biz" öznesi ile Türk milletinin fertlerinin tamamına atıf yapılmaktadır. Türklerin irredentist olmayan bir milliyetçiliği benimsedikleri ve yurtlarını ne pahasına olursa olsun savunacakları belirtilmektedir. Bu diskur, alıntının son cümlesinde askerliğin yaşam ve ölüme eş değer tutulması ile zirve yapmaktadır. İkinci alıntıya hâkim olan diskur da aynı şekilde askerlik ve orduyu yüceltmektedir. Alıntılarda, Türklerin asker bir millet olduğunun, yurt savunmasında can vermenin kutsal olduğunun ve askere gitmenin yaşamak kadar gerekli ve doğal olduğunun vurgulanması, askerliği çekici hale getirmek amacına yönelik olduğu savunulabilir. Önemli ulusal güvenlik problemlerinin canlı olduğu bir coğrafyada güçlü bir ordu bulundurma ihtiyacına dönük olarak ordu ve askerliğin pozitif bir temsilinin yapılması, zorunlu askerliğin anayasal bir vatandaşlık ödevi olduğu Türkiye'de askerliği çekici hale getirme amacı taşıdığı ileri sürülebilir. Altı çizilmesi gereken nokta, alıntıya hâkim bu diskur orduyu önemli bir kurum olarak resmetse de bir önceki dönemdeki gibi, orduyu politika üzeri bir yere konumlandırmamaktadırlar. $\mathrm{Bu}$ militarist diskurda önemli bir değişime işaret etmektedir. Ordunun politik sistemin bekçisi, siyaset üzeri rolü, 1960 darbesinin anlatıldığı bölümlerde de geçmişe kıyasla daha az vurgulanmaktadır:

Fakat 1954 yllından sonra iktidar partisinin yönetiminden şikâyet edilmeye başlandl. Yapılan yatırımlar planlı bir şsekilde yürütülemediğinden yeteri kadar sermaye bulunamadl. Türk parasının değeri düşü̈. Yiyecek ve eşya fiyatları yükseldi. Muhalefet partileri ve basın iktidar partisini eleştirmeye başladılar. İktidar bu duruma karşs sert tedbirler aldı. Bunun üzerine iktidarın Anayasaya ve diğer kanunlara aykır davranışlarda bulunduğu ileri sürüldü. Muhalefet partileriyle iktidar partisi arasındaki tartışmalar gittikçe şiddetlendi. Ülkede dirlik ve düzen bozuldu. Bir kardeş kavgası çımasından kuşku duyulmaya başlandı.

Türk Silahlı Kuvvetleri, tehlikeli gördükleri bu duruma son vermek için 27 Mayıs 1960 Cuma günü harekete geçerek devlet yönetimini geçici bir süre için eline aldl. İktidar partisi iş başından uzaklaştırıldı.

Bu devrimin amacı milletin birliğini, devletin varlığını ve bütün hürriyetleri să̆lamaktı.

27 Mayls devrimi memlekette büyük sarsintı yapmadı. Klsa zamanda normal hayata dönüldü (Asal, Akşit, ve Sanır, 1975, ss.116-117).

Bir önceki dönemde "27 Mayıs Devrimi” başlıklı bölümlerde darbeye dair detaylı anlatım yapılmasının aksine 1970'lerin sosyal bilgiler ders kitaplarında 1960 darbesi bu alıntıdaki şekliyle anlatılmıştır. Bu bölüm aynı şekliyle iki farklı ders kitabında da yer almıştır (Akşit ve Sanır, 1973; Asal ve diğerleri, 1975). Bu bölümde DP iktidarı dönemi negatif bir şekilde anlatılmaya devam etse de biraz daha nüanslı bir dil kullanılmıştır. Örneğin, "iktidarın Anayasaya ve diğer kanunlara aykırı davranışlarda bulunduğu ileri sürüldü” ifadesi, geçmiş ders kitaplarındaki, "Bu ihtilal (...) gerici zümreyi ezmesidir" (Aksan, 1963, s. 39) gibi ifadelere kıyasla daha 1lımlı ve nüanslı gözükmektedir. Aynı şekilde, 27 Mayıs darbesi bir "devrim” olarak nitelenmeye, olumlanmaya 
ve yüceltilmeye devam etse de bu darbenin pozitif temsiline dönük diskurlarda bir azalma söz konusudur. Ayrıca, 1971 askeri muhtırasına dönük herhangi bir atıf da tespit edilmemiştir. Bu bulgular, ordunun anti-demokratik konum ve eylemlerinin normalize edilmesine dönük söylemlerde bir gerileyişe işaret etmektedir.

Bu dönem ders kitaplarında, militarist diskurun diğer göstergeleri tamamen yok olmamış daha örtük bir şekilde ifade edilmiştir. Örneğin, ders kitaplarından birisinde "...topraklarımıza göz diken, saldırgan emeller besleyen komşularımız bulunduğuna göre...” (Asal ve diğerleri, 1975, s. 15) şeklinde zenefobik bir tutumu yansıtan ifadelere yer verilmiştir. Aynı ders kitabında, yürütme organlarından birisi olarak 1960 darbesinden sonra ihdas edilen MGK'ya dair şu ifadeye yer verilmiştir: "Milli Güvenlik Kurulu, yurdun ve milletin güvenliği ile ilgili kararların alınmasında ve iş birliğinin sağlanmasında gerekli temel görüşleri Bakanlar Kurulu'na salık verir" (s. 35). Bu cümledeki "salık verir" fiili, hiyerarşik olarak MGK'yı Bakanlar Kurulu'nun üzerinde konumlandırmaktadır. Bu ifade, 1960 darbesi sonrası revize edilen ders kitaplarında daha belirginleşen, orduyu demokratik kurumlar üzeri bir yerde konumlandıran militarist diskurun örtük bir ifadesi olarak görülebilir. Alıntılanan bu ifadeler, aynı ders kitabının 1984'de revize edilmiş baskısından tamamen çıkarılmıştır. Ders kitabının 1984 versiyonunda, 1960 darbesi ile ilgili olan bölümler tamamen kaybolmuş, darbelere dair hiçbir bilgi verilmemiştir (Asal ve diğerleri, 1984). Ayrıca, MGK'ya ilişkin cümle şu şekilde modifiye edilmiştir: "Kurulun, (...) alınmasını zorunlu gördüğü önlemlerle ilgili kararlar, Bakanlar Kurulu'nca öncelikle dikkate alınır" (Asal ve diğerleri, 1984, s. 37). "Salık verir" fiilinin "dikkate alınır" şeklinde modifiye edilmesi ile MGK ve Bakanlar Kurulu arasındaki hiyerarşik ilişki biraz daha demokrasi ilkelerine yakın hale getirilmiştir. Bu bulgular, 1980 darbesinin sosyal bilgiler ders kitaplarını etkilemediğini göstermektedir. Fakat bu durum, 1980 darbesinin müfredata bir etkisi olmadığ anlamına gelmemelidir, bilakis daha sonraki yıllarda yayımlanacak ders kitaplarında darbenin belirgin bir etkisi gözlemlenecektir.

Vatandaşlık bilgileri dersi (1985-1995): 1980 darbesinin sosyal eğitimdeki en belirgin etkisi, 1985 yılında sosyal bilgiler dersinin kaldırılarak, yerine yeni üç dersin (Milli Tarih, Milli Coğrafya ve Vatandaşlık Bilgileri) müfredata konulması ile somut hale gelmiştir (MEB, 1985). Vatandaşlık Bilgileri ders kitaplarında militarist diskurlar daha belirgin hale gelmiştir. Önceki ders kitaplarında dış dünyayı ve komşu ülkeleri düşman olarak ima eden veya kısaca belirtip geçen ifadeler netlik kazanmış, hatta bu konu hakkında yeni bölümler, yeni başlıklar ders kitaplarına eklenmiştir. Örneğin, ders kitabında "Rejimimize ve Varlığımıza Yönelen Tehditler" (Dal ve diğerleri, 1986, s. 100), "Güçlü Türkiye'nin Arzulanmayışı" (s. 101), "Anarşi ve Terör" (s. 101), "Global Tehdit" (s. 102), "Güncel Tehdit", "İç Tehdit", "Dış Tehdit" (s. 103) gibi konulara ayrı bölümler halinde yer verilmiştir. "Türkler asker millettir" miti bu ders kitabında da devam edegelmiştir. Türklerin barışçı bir millet olduğu, başka ülkelerin topraklarında gözlerinin olmadığı, ancak kendi ülkelerine bir başka ülkenin göz dikmesi veya saldırması durumunda, "coşkun bir sel gibi önündeki bütün düşman kuvvetlerini” ezip geçeceği ifade edilmiştir (s. 172).

Vatandaşlık Bilgileri ders kitaplarında demokrasinin negatif temsili sayılabilecek ifadelere de yer verilmiştir. Örneğin, ülkeye zarar vermek isteyen "yıkıcı ve bölücü" unsurların 1950'de kurulan çok-partili parlamenter demokrasiden yararlandıkları, böylece ülkedeki "demokratik düzeni" yıkmaya çalıştıkları ifade edilmiştir (Dal ve diğerleri, 1986, s. 72). Demokrasi karışıklık ve kaos çıkarmaya elverişli bir rejim olarak resmedilmiş, bir taraftan "yıkıcı ve bölücü" unsurların yararlanarak güçlendikleri, diğer taraftan yıkmaya çalıştıkları bir rejim olarak sunulmuştur. Önceki dönem ders kitaplarında muğlak kalan iç tehdit ve iç düşman söylemi bu ders kitabında netleştirilip karakterize edilmiştir. Önceki ders kitapları, ülkede yaşayan insanları iç tehdit unsuru olarak resmetmekten kaçınarak cephe gerisine sızan düşmanların karışıklık çıkarabileceğinden bahsederken (Şerbetçioğlu ve Tülin, 1958), bu ders kitabı artık ülke içerisinde yaşayan bazı kesimleri "yıkıcı ve bölücü" unsur olarak nitelemektedir. Böylece artan ulusal güvenlik endişeleri üzerinden 12 Eylül 1980 darbesi şu şekilde meşrulaştırılmaktadır: 
Bilindiği gibi 12 Eylül 1980 tarihinden önce ülkemiz, teröristlerin gönüllerince at oynattıkları; hukuk, ahlak, din, Türk gelenek ve görenekleriyle bağdaştırılmasına imkân olmayan, kanlı olayların sergilendiği bir ülke haline gelmişti. O kadar ki bu olaylar planlayanlar Türkiye'yi bölüp yok etme hedeflerine hayli yaklaştıklarını sandıkları bir sirada 12 Eylül Harekâtı bu oyunlara son verdi; tertiplerin, kanlı olayların meyvelerini toplamaya hevesli olanları zafer sarhoşluğundan uyandirdl.

Kısaca, atalarımızın kanları ile sulanan bu güzel ülkemiz, tarihin derinliklerinden beri hür ve bağımsı yaşamayı kendine düstur bilmiş büyük milletimiz, bir tehlike ve tehdit altındaydl. 12 Eylül Harekât, ülkemizi içine düştüğü durumdan kurtarmak, devlet yönetimine yeniden işlerlik kazandırmak, büyük ölçüde zedelenen milli birlik ve bütünlügümüz ile demokratik rejimimizi yeniden ve sağllklı bir şekilde korumak amacıyla Türk Silahlı Kuvvetleri tarafindan başarı ile gerçekleştirilmiştir (Dal ve diğerleri, 1986, s. 100).

1960 sonrası ders kitaplarındaki gibi, darbe "devrim, ihtilal" olarak sunulmayıp "harekât" olarak nitelense de bu kavram olumlu bir manada kullanılmıştır. "Harekât" kavramı ile hükümeti deviren, siyasi partileri kapatan ve askeri bir idare kuran bir darbe değil, ülkeyi kurtaran önemli bir askeri operasyona atıf yapılmıştır. Bu "harekât" 1 meşruiyeti ise "teröristler, yıkıcı ve bölücü unsurlar" yani kısaca iç tehdit unsurlarının eylemleri üzerinden sağlanmıştır. İç tehdit unsurlarının hâkim sosyal grubun (Türk milleti) değerlerini ihlal ettikleri (value violation), şiddet olaylarının failleri oldukları ve ülkeyi yıkma amacında oldukları ifade edilerek, düşman-öteki olarak konumlandırılan bu grupların negatif özellikleri vurgulanmış, biz olarak konumlandırılan "Türk milleti”nin ise pozitif özellikleri ("hür ve bağımsız yaşamayı kendine düstur bilmiş büyük milletimiz”) ön plana çıkarılmıştır. Darbeyi meşrulaştıran bu bölüm, ders kitabının 1994 baskısından tamamen çıkarılmıştır (Dal ve diğerleri, 1986; Dal ve diğerleri, 1994). Aynı şekilde, ders kitabının 1986 versiyonunda, Rusya'yı bir dış tehdit olarak belirten ifadeler de ders kitabının 1994 baskısında kaybolmuştur.

$\mathrm{Bu}$ alıntıdaki darbe anlatımında, ordunun hükümeti devirmesinin veya görevden uzaklaştırmasının belirtilmemiş olması önemli bir değişikliktir. Ders kitaplarının 1960 darbesi sonrası versiyonlarında ordunun hükumeti devirmesi açık açık belirtilmiş, olumlanmış ve hatta yüceltilmişti (Aksan, 1963; Şerbetçioğlu ve Tülin, 1962). Vatandaşlık bilgileri dersi kitabında, sadece 1980 darbesi anlatımında değil 1960 darbesine atıf yapılırken de ordunun seçilmiş bir iktidarı devirmesi gizlenmiş, darbeler farklı bir biçimde sunulmuş ve iktidarın seçimle iş başına gelmesi övülmüştür. "Devrim, ihtilal" kavramları yerine darbenin bir "harekât" olarak sunulması da bu gizleme ihtiyacından kaynaklanmış olabilir. Şu alıntı, darbelere dair hâkim diskurdaki bu önemli değişimi örneklendirmektedir:

1950 seçimlerinde, ilk defa, Türk Milleti, kullandiğ oylarla İktidar partisini (CHP) yönetimden indirmiş, onun yerine Demokrat Parti'yi yönetime getirmiştir. Bu olay, Türk Milleti için yepyeni ve demokraside millet hakimiyetinin neler yapabileceğini gösteren bir uygulama olmuştur.

27 Mayıs 1960’ta DP devlet idaresinden düşürülmüş̧tür.

1961 'de yeni bir Anayasa yürürlüğe girmiştir. 1961 Anayasası demokraside yeni bir aşama oluşturmuştur (Dal ve diğerleri, 1986, s. 96).

Alıntılarda, 1950'de hükumetin seçimle el değiştirmesini olumlu bir gelişme olarak resmedilmiş ve ordunun hükümeti görevden uzaklaştırması ise açıkça belirtmemiştir. Alıntılarda ordu pozitif bir dille sunulsa da ordunun askeri darbe yaptığını gizleme çabası söz konusudur. Örneğin, üçüncü cümledeki pasif “düşürülmüştür” yüklemi ile darbenin faili gizlenmektedir. Artık ordu darbe yapan bir özne olarak ön plana çıkarılmamaktadır. Ders kitabına yansıyan bu diskur değişiminin önce ordunun kendi kurumsal alanında geliştiği ve daha sonra pedagojik alanda ifade edildiği ileri sürülebilir. Bu değişim, 1980 sonrası liberal market ekonomisine geçiş 
yapan Türkiye'de ordunun kendisini daha demokratik bir kurum olarak resmetmek istemesinden kaynaklanmış olabilir (Blad ve Koçer, 2012).

Vatandaşlık ve insan hakları eğitimi dersi (1995-2005)

1995 yılında MEB Birleşmiş Milletler İnsan Hakları Eğitimi On Yılı projesine katılarak Vatandaşlık Bilgileri dersini Vatandaşlık ve İnsan Hakları Eğitimi olarak yeniden isimlendirmiştir (MEB, 1995). Bu isim değişikliği sonrası, dersin öğretim programına insan hakları ile ilgili konular eklenmiş ve 1996-97 eğitim-öğretim yılından itibaren yeni ders kitapları kullanılmaya başlamıştır. 1998'de Vatandaşlık ve İnsan Hakları dersi için yeni bir öğretim programının yayımlanmasından sonra, 1999-2000 eğitim-öğretim y1lından itibaren yeni programa göre hazırlanmış ders kitapları 2005 müfredat reformu ile bu ders kaldırılıncaya kadar okutulmuştur (MEB, 2005). Vatandaşlık ve insan hakları eğitimi dersinin 1996-1999 yıllarında kullanılan ders kitaplarında, orduyu demokrasi üzeri bir yere konumlandıran militarist diskurun devam ettiği tespit edilmiştir. Vatandaşlık dersine insan hakları konularının eklenmesi ve dersin başlığında insan hakları kavramının yer alması militarist diskurda önemli bir fark yaratmamıştır:

Atatürk, inkılapların güvencesini orduda gördüğ̈̈ için; 'Ordumuz, Türk topraklarının ve Türkiye idealini gerçekleştirmekte olduğumuz sistemli çalışmaların, yenilmesi imkânsiz güvencesidir.' demiştir.

Her zaman milli birliğin simgesi ve cumhuriyetimizin koruyucusu olan ordumuz, Atatürk’ün gösterdiği yolda görevini başarll olarak sürdürmektedir (Tanır, 1997, s. 120).

Orduyu "inkılapların güvencesi" ve "cumhuriyetimizin koruyucusu" olarak tanıtan, ordu ve demokrasi arasında herhangi bir ilişki kurmayan bu ifadeler, bu çalışmada incelenen militarist diskuru örneklendirmektedir. Ordu'nun sistem koruyucusu, demokrasi üzeri konumu, Atatürk'ün nerede, hangi şartlarda ve hangi amaçla söylediğine dair hiçbir detay verilmeyen bir sözü ile kanıtlanmaya çalışılmaktadır [authorization] (Van Leeuwen, 2007). Alıntılanan bu ders kitabında, önceki ders kitaplarından farklı olarak, demokratikleşme tarihi anlatılırken darbelere "devrim, ihtilal veya harekât" gibi kavramlarla herhangi bir atıf yapılmamıştır. Aksine, 1950'de iktidarın seçimle el değiştirmiş olması takdir edici bir dille anlatılmış, darbelerden sadece birisi, “1960'da Demokrat Parti iktidardan uzaklaştırıldı" şeklinde fail gizlenerek ayrıntısız verilmiş, diğer darbelere dönük hiçbir gönderme tespit edilmemiştir (Tanır, 1997, s. 61). Fakat incelenen diğer ders kitabında darbelere şu şekilde gönderme yapılmıştır:

27 Mayıs 1960 yılında DP, Türk Silahlı Kuvvetlerinin demokrasiye yaptığı bir müdahale sonucu yönetimden uzaklaştırılmıştır.

12 Mart 1971 tarihinde Türk Silahl Kuvvetleri, hazırladıkları bir muhtıra ile demokrasiye ikinci kez müdahale etme gereği duymuşlardır.

12 Eylül 1980 tarihinde, yine Türk Silahlı Kuvvetlerince 12 Eylül Harekâtı gerçekleştirilmiş ve yönetime el konulmuştur (Yiğit ve Turan, 1996, s. 93).

Bu ifadelerde, geçmişten farklı olarak TSK bir aktör olarak öne çıkarılıp, TSK'nın eylemi "yönetimden uzaklaştırma, müdahale ve yönetime el koyma" olarak nitelense de "darbe" kavramı kullanılmamış, askeri müdahalelere dönük açık bir eleştirel ton tespit edilmemiştir. Fakat TSK'nın eylemlerinin belirtilen fiillerle ifade edilmiş olması, geçmişe kıyasla darbelere ilişkin daha negatif bir diskurun hâkim olmaya başladığını ima etmektedir. Nitekim, alıntıdaki cümlelerde, 27 Mayıs ve 12 Mart "müdahale" olarak kritik bir dille ifade edilirken, ders kitabının yayımlandığ olarak olumlanmıştır.

Tanır (1997) tarafından yazılan ders kitabında, askerlik kutsaldır, ordu eğitim alınan bir okuldur gibi askerliği çekici hale getirme amacı taşıyan ifadeler ve Türkler barışseverdir, fakat gerektiğinde düşmanlara gereken cevabı vermeye hazırdır, Türkler kahraman bir millettir gibi 
savunmacı milliyetçi söylemler devam edegelmiştir. "Anarşi ve Terör" (Tanır, 1997, s. 63), "Global Tehdit" (s. 65), "Güncel Tehdit" (s. 65), "İç Tehdit" (s. 65), "Dış Tehdit" (s. 66) gibi konuların kapsamı artırılmış ve daha detaylandırılmıştır. Ayrıca "Türkiye'nin kalkınmasını istemeyen bazı ülkelerin etkinlikleri" (s. 67), "İstihbarat etkinlikleri” (s. 67), "Terörle Mücadelede Kişilere Düşen Görevler" (s. 67) gibi yeni bölümler ve "milli güvenlik, milli hedef, milli güç" (s. 120) gibi yeni kavramlar ders kitabına girmiştir. Milli güvenliği ilgilendiren bu bölümlerde, savaşların vuku bulma şeklinin değiştiğine dönük diskur tekrar edilmiş ve düşman ülkelerin iç düşmanlar aracılığıyla Türkiye'yi yıkmaya çalıştıklarından bahsedilmiştir:

Terör örgütleri, Türk devletine dost olmayan bazı komşu ülkelerden gördükleri destek sonucunda... (Tanir, 1997, s. 64).

Düşmanlar, bizi yıkmak için yüzyıllardır çalışmışlar hala da çalışmaktadırlar (Tanır, 1997, s. 65).

Güneydoğu Anadolu Projesi’ni engellemek isteyen komşu ülkeler ... (Tanır, 1997, s. 67).

Bu devletler, kendi çıkarları doğrultusunda çalışarak ülkemizi bölmek, parçalamak ve rejimimizi yıkmak amacıyla yıkıcı ve bölücü örgütleri desteklemektedirler (Tanır, 1997, s. 67).

Bir önceki dönem ders kitabının kullanıldığı yıllar içerisinde sadeleştirildiği ve bazı antidemokratik bölümlerin bu ders kitabından çıkarıldığı göz önüne alındığında (Dal ve diğerleri, 1986; Dal ve diğerleri, 1994), bu bölümde alıntılanan ders kitabında militarist diskurlar önemli bir artış göstermiştir. Yapılan alıntıların örneklendirdiği gibi, Türkiye'nin iç ve dış tehditlerle çevrili olduğunu vurgulayan kuşatılmışlık algısı ve ordunun hayatiliğini ön plana çıkaran zenofobik bir diskur ders kitaplarına hâkim olmaya bașlamıștır. Bu diskur ülke içerisindeki "yıkıcı ve bölücü” örgütlerin dış güçlerden yardım aldığını, iç ve dış düşmanların iş birliği içerisinde hareket ederek Türkiye'yi bölmeye ve yıkmaya çalıştığını ifade etmektedir.

28 Şubat 1997 tarihinde, ordunun müdahaleleriyle politik İslamcı Refah Partisi tarafından kurulan koalisyon hükumetinin yönetimden uzaklaştırılması sonrasında, ordu direktifleriyle politik İslamcılık ideolojisini yok etmek için bazı önlemler alınmıştır. Örneğin, okullarda başörtüsü yasağı, imam-hatip lisesi mezunlarının seküler lisans programlarına alınmaması, imamhatip ortaokullarının ve Kuran kurslarının kapatılması bu önlemler arasında sayılabilir (Ozgur, 2012). Sekülarizmi yeniden tesis etmek için alınan bu önlemler kapsamında öğretim programı ve ders kitaplarında da önemli değişiklikler olmuştur. 1998 yılında, Vatandaşlık ve İnsan Hakları Eğitimi dersi için yeni bir öğretim programı, 1999'da ise bu ders için yeni bir ders kitab1 yayımlanmıştır (Çiftçi ve diğerleri, 1999). Dersin 2005'te kaldırılmasına kadar kullanılan bu ders kitabı, militarist diskurların en yoğun biçimde yer aldığı ders kitabıdır. 1999 Helsinki Zirvesi Sonrası döneme girmeden, yani AB'nin Türkiye'ye aday ülke statüsü vermesinden kısa bir süre önce yayımlanan bu ders kitabında, ordunun anti-demokratik konum ve eylemlerini normalize eden diskurlar adeta zirve yapmıştır. Bu ders kitabı, AB müzakereleri hızlandıktan sonra, 2004 yılında revize edilse de militarist diskurların en yoğun olduğu vatandaşlık ders kitabı olma özelliğini sürdürmüştür (Çiftçi ve diğerleri, 1999, 2004).

Bu ders kitabını oluşturan dört üniteden, "Milli Güvenlik ve Milli Güç Unsurları" başlığı taşıyan üçüncüsü, en uzun ve en kapsamlı olanıdır ve tamamen milli güvenlik konularına ayrılmıştır (Çiftçi ve diğerleri, 1999). Toplamda 127 sayfalık ders kitabının 31 sayfası bu üniteye ayrılmıştır. Bu ünitenin sayfa sayısı, insan hakları ile ilgili olan diğer iki ünitenin toplam sayfa sayısından, 26 sayfa, daha fazladır. Ayrıca bu milli güvenlik ünitesi dışındaki diğer üç ünitede de militarist diskurlara yoğun bir şekilde yer verilmiştir. Bu ders kitabında, önceki dönem ders kitaplarında tespit edilen ordunun anti-demokratik konum ve eylemlerine dönük ifadeler daha detaylandırılmış, ordunun ayrıcalıklı konumu daha çok vurgulanmış ve tehdit algısına dönük bölümlerin kapsamı daha genişletilmiştir. Darbeleri gizlemeye dönük gelişen diskur bu ders 
kitabında daha belirgin hale gelmiş ve geçmiş ders kitaplarından farklı olarak darbelerle ilgili herhangi bir bilgiye yer verilmemiştir. Ayrıca önceki dönem ders kitaplarında tespit edilen siyasi partilerin kuruluş gerekçeleri ve görevleri, muhalefetin görevleri gibi konulardaki açıklamalar bu ders kitabından tamamen kaybolmuştur. Ordunun seçilmişlerin idaresi altında değil, politik rejimin koruyucusu olarak sistem-üzeri bir yerde konumlanması ve çeşitli eylemlerde bulunmasını normalleştiren militarist diskuru şu alıntılar yansıtmaktadır:

Türk devletlerinde bu durum askeri gücün hemen her şeyden önce geldiği ve toplumda egemen güç düzeyine eriştiği görülmüş̧ür (Çiftçi ve diğerleri, 1999, s. 62).

...iç tehdite karşı, anayasa ve yasaların öngördügü hükümler çerçevesinde, Türk silahlı kuvvetleri duruma müdahale edebilir. Anayasanın ve TBMM'nin kendine verdiği görevleri yerine getirir (Çiftçi ve diğerleri, 1999, s. 63).

Milli gücü oluşturan unsurlar içerisinde askeri güç, caydırıcılık ve yaptırım açısından en etkili olanıdır. (...) Türk Silahl Kuvvetleri, ulusun bağrından çıkmış, ordu-millet bütünlügünün simgesidir. (...) Genelkurmay başkanı, başbakana karşı sorumludur (Yiğit, 2007, s. 96).

$\mathrm{Bu}$ ifadelerde ordunun anti-demokratik konum ve eylemleri normalmiş ve hatta yasal bir gereklilikmiş gibi sunulmaktadır. İlk cümlede, askeri gücün "her şeyden önce geldiği” ve "egemen güç düzeyine eriştiği"nden bahsedilmektedir. Böylece, ilk alıntı demokrasi teorisi içerisinde herhangi bir meşruiyet zemini sunmadan, askeri gücün "egemen güç" olduğunu vurgulamaktadır. İkinci alıntıdaki "duruma müdahale edebilir" ifadesi, ordunun ülke içerisinde, bir gereklilik hissettiği zaman rol alabileceğini anlatmaktadır. Burada öncelikle anayasa ve yasaların vurgulanması, bu iki unsurun TBMM'den önce zikredilmesi anlamlıdır. Zira anayasa ve yasalar, yani 1982 anayasas1, askeri hükumet dönemlerinde, ordunun demokrasi üzeri konumunu konsolide etme amacı güdülerek hazırlanmıştır (Üstel, 2004). Orduya ayrıcalıklı bir konum tanıyan, ordu gözetiminde yazılmış bir anayasaya atıf yapılarak ordunun "duruma müdahale” edebileceğinin meşrulaştırılması, TBMM'nin ikincil önemde zikredilmesi, militarist diskura hizmet etmektedir.

Üçüncü alıntı ise ordu ve milletin organik bir bütün olduğunu ifade etmektedir. Bu diskur, ordu milletin bağrından çıkmıştır, milletin sembolize halidir, dolayısıyla ordu demokratik bir meşruiyete sahiptir imasını içermektedir. Demokratik sistem içerisinde ayrıcalıklı bir konumda bulunan ordu, demokratik sisteme tabi değil, onun koruyucusu ve kollayıcısı statüsünde resmedilerek, ordunun, seçilmiş iradenin, yani Bakanlar Kurulu, Başbakan veya TBMM'nin idaresi altında olmasının çok da gerekli olmadığı, çünkü kendisinin de milli iradeyi temsil ettiği ima edilmektedir. $\mathrm{Bu}$ diskuru destekleyen 1982 Anayasası'ndan, "Genelkurmay başkanı, başbakana karşı sorumludur" maddesi alıntılandırılarak Genelkurmay başkanının, milli iradeyi temsil eden Başbakanlık, Bakanlar Kurulu, TBMM gibi kurumlara bağlı, onların emrinde veya kontrolünde olmadığı normalize edilmektedir (Yiğit, 2007, s. 96). Askerleri yürüyüş halinde resmeden bir görselin altına not düşülen "Ordumuz, cumhuriyetimizin bekçisidir" ibaresi bu antidemokratik diskuru normal ve meşru olarak yeniden üretmektedir (Çiftçi ve diğerleri, 1999, s. $64)$.

Son olarak, bu dönem ders kitaplarında, askerliğin kutsallığı (Çiftçi ve diğerleri, 1999, s. 64), Türklerin asker bir millet olduğu (s. 62), ordunun aynı zamanda bir eğitim kurumu olduğu (s. 34), Türklerin barışçı bir millet oldukları ancak bağımsızlıklarına bir saldırı olduğunda canları pahasına yurtlarını savunacakları (s. 64), Türkiye'nin güçlenmesini istemeyen düşman devletlerin Türkiye'de sürekli "terör ve kargaşa" ortamı yaratmak için iç düşmanları destekledikleri (s. 81), iç düşmanları destekleyen düşman ülkeler arasında Türkiye'nin dost zannettiği komşu ülkelerin de olduğu (s. 80) gibi diskurlar zenginleşerek devam edegelmiştir. İç tehdit temasını abartılı bir biçimde işleyen bu diskurlar, önceki dönem ders kitaplarında sıklıkla "yıkıcı ve bölücü" unsurlara atıf yapılarak anlatılırken, bu dönem ders kitaplarında "bölücü ve yıkıcı" sıfatlarının yanına yeni 
bir sıfat eklenerek "bölücü, yıkıcı ve irticai" olarak karakterize edilmiştir (s. 77). Eklenen bu yeni sıfat, 28 Şubat 1997 askeri müdahalesi döneminde, ordunun politik İslamcıları da iç tehdit unsurları listesine eklediğine işaret etmektedir.

Vatandaşlık ve demokrasi eğitimi dersi (2010-2012): Asker-kontrollü çok partili hayat döneminin (1946-1999) en son ürünü olan vatandaşlık ve insan hakları eğitimi ders kitapları, Helsinki Zirvesi sonrası dönemde de bir süre okutulmaya devam etmiştir. İncelenen Çiftçi ve diğerleri, (1999) tarafından yazılan ders kitabındaki militarist diskuru destekleyen birçok bölüm, bu ders kitabının 2004 'te revize edilen yeni versiyonunda (Çiftçi ve diğerleri, 2004) değiştirilmiş veya tamamen çıkarılmıştır. 2005 'de yapılandırmacılık felsefesi temelinde yapılan müfredat reformu ile bu dersler tamamen kaldırılınca, bu ders kitapları da kullanımdan kaldırılmıştır (MEB, 2005). 2005 yılında MEB'in AB kapsamında, geleneksel öğretmen merkezli eğitimi öğrenci-merkezli yeni bir anlayışla değiştirme hamlesi ile militarist diskuru destekleyen ifadelerin büyük bir bölümü ders kitaplarından çıkarılmıştır. Vatandaşlık dersleri kaldırıldıktan sonra, 2005'ten 2010 yılına kadar ilköğretim 8. sınıfta herhangi bir vatandaşlık dersi okutulmamıştır. Avrupa Konseyi'nin Demokratik Vatandaşlık ve İnsan Hakları Eğitimi projesi kapsamında, 2010 yılında Vatandaşlık ve Demokrasi Eğitimi başlıklı yeni bir ders müfredata konulmuştur (MEB, 2010). Bu derse ait incelenen iki ders kitabında, geçmişte tespit edilen militarist diskurlardan hiçbirisine rastlanmamıştır (Aşan, 2014; Özpolat, 2012). Ordu ve askerlik ile ilgili bu ders kitaplarından birisine giren tek ifade askere gitmenin bir vatandaşl1k ödevi olduğudur (Özpolat, 2012, s. 41 ve s. 128). Ayrıca eski dönem ders kitaplarında askeri görsellerin yoğunluğunun aksine, bu derse ait kitaplarda ordu ile ilişkilendirilebilecek görsellere çok az yer verilmiş, Atatürk'ün sivil kıyafetli resimleri ön plana çıkarılmış, haklar evrensel insan hakları belgelerine (Çocuk Hakları Sözleşmesi ve Evrensel İnsan Hakları Beyannamesi) atıflarla temellendirilmiştir. Bu ders 2012'de yapılan 4+4+4 eğitim reformu ile kaldırılmasına rağmen, militarist diskurun vatandaşlık ders kitaplarından çıkarılmasında önemli bir aşamayı temsil etmiştir (MEB, 2012). Sonuç olarak, AB reformlarıyla ordunun sistemdeki ayricalıklı konumunun sinırlandırılmasına paralel olarak, militarist diskurlar da incelenen ders kitaplarından büyük ölçüde çıkarılmıştır.

\section{Tartışma, Sonuç ve Öneriler}

1950-2005 arası dönemde militarist diskurlardaki devamlılık ordu ile eğitim arasındaki yerleşik bir ilişkinin varlığına işaret etmektedir. Kaplan (2006) Türkiye'de ordu ve eğitim arasındaki bu ilişkiye dair bir sessizlik olduğunun altını çizmiş ve bu ilişkiyi bir akrabalık ilişkisi [symbiosis] ve benzeşiklik [homology] olarak nitelemiş fakat buna dair fazla detay sunmamıştır (s. 174). Altınay (2004) ise, çalışmasına katılan bir komutandan aktararak, Türkiye'de sadece Milli Savunma ve Milli Eğitim Bakanlıkları'nın milli sıfatını aldıklarını ve bu iki devlet aygıtının yurt savunması ve bağımsızlığı için en temel kurumlar olduğunu not etmiş, eğitim ve askerliği millet inşa etme süreçlerinin iki yüzü olarak tarif etmiştir. Sen ve Starkey (2017) 1998 vatandaşlik ve insan hakları eğitimi dersi öğretim programının, 28 Şubat 1997 darbesi sonrasında MGK Genel Sekreterliği'nde incelenip revize edildiğine dair bulgular elde etmiş, ordu-eğitim arasındaki yerleşik ilişkiye 1şık tutmuştur. Mevcut çalışma, militarist diskurların ordunun kurumsal alanında üretilerek eğitimde pedagojik amaçlarla yeni bir bağlama uyarlandığını [recontextualization], ders kitaplarındaki militarist diskurları tespit etmek suretiyle göstermiş̧ir (Bernstein, 2003). Ayrıca, mevcut çalışma, zikredilen çalışmalara, ordu-eğitim arasındaki yerleşik ilişsinin bir başka boyutunu göstererek katkıda bulunmuştur. Bu boyut, ordunun demokratik norm ve prensiplere uymayan konum ve eylemlerinin, amaçlarından birisi demokrasi eğitimi olan Türkiye Cumhuriyeti eğitim sistemi içerisinde olumlanması, meşrulaştırılması ve hatta yüceltilmesidir. Mevcut çalışmanın yoğunlaştığ dönemler içerisinde, özellikle 1985 sonrası okutulmaya başlanan vatandaşlık bilgileri dersi ile milli güvenlik konuları vatandaşlık dersi müfredatının bir parçası olmuş, bir tehdit algısı üzerinden ordunun önemi vurgulanarak ordunun anti-demokratik konum ve eylemleri normalize edilmiştir.

1950-2005 yılları arasında, ordunun anti-demokratik konum ve eylemlerini meşrulaştıran militarist diskurlarda önemli değişiklikler olmuş fakat düzenli bir azalma tespit edilmemiştir 
Özellikle darbe sonrası dönemlerde yoğunlaşan militarist diskurlar en belirgin biçimiyle 1997 darbesi sonrası döneme ait ders kitaplarında gözlemlenmiştir. 1980 sonrası dönemde artan ve 1997 sonrası zirve yapan militarist diskurlara dair emareler, 1999 Helsinki Zirvesi sonras1 dönemde $\mathrm{AB}$ uyum yasaları ile önemli ölçüde azalmıştır. $\mathrm{AB}$ üyeliğine hazırlık retoriğinin etkin kullanımı yoluyla gerçekleştirilen 2005 müfredat reformu, militarist diskurlarda önemli bir azalış getirmiştir. Öğrenci-merkezli bir eğitim anlayışını hakim kılma amacı taşıyan bu reform sonrasında, okullarda demokratik pratiklerin arttı̆̆ını ve ders kitaplarında militarist diskurların azaldığını diğer araştırmalar da teyit etmektedir (Altinyelken, 2015; Kancı ve Altınay, 2007; Kanci, 2009). Bu son dönemin eğitimi de-militarize etmedeki katkısını bir kenara koyarsak, militarist diskurların, vatandaşlık derslerinin sosyal bilgiler dersinin bir parçası olduğu 1968-1985 arası dönemde de önemli ölçüde azaldığı ileri sürülebilir. Üstel (2004) de bu dönem okutulan sosyal bilgiler derslerinin daha demokratik olduğunu tespit etmiştir. Orduyu kutsamaya dönük aşırı militarist ve milliyetçi diskurlar bu dönem ders kitaplarına yansımasına rağmen, ordunun anti-demokratik konum ve eylemleri, diğer ders kitaplarına kıyasla, daha az olumlanmış ve meşrulaştırılmıştır.

Demokratik rejimi devam ettirip geliştirecek demokrat vatandaşlar yetiştirmek Türkiye eğitim sisteminin amaçlarından bir tanesidir. $\mathrm{Bu}$ amacın gerçekleşmesini, ordunun demokrasiüzeri bir yere kendisini konumlandırması ve buradan çeşitli anti-demokratik eylemlerde bulunmasını meşrulaştıran militarist diskurların eğitim yoluyla yayılması olumsuz yönde etkilemiştir. Ordu her ne sebeple bu diskurları yaymış olursa olsun, bu çalışmanın altını çizdiği en önemli nokta, eğitim yoluyla yayılan bu militarist diskurların, sosyal eğitimin demokratikleşmesi ve Türkiye'de demokrasi kültürünün gelişmesi açısından oldukça olumsuz bir durum olmasıdır. Örneğin, militarist diskurların yayılması, vatandaşların darbeleri yapılabilir veya yapılmasında bir mahzur olmayan bir eylem olarak kodlaması ve böylece demokrasi ile yönetilen bir ülkede darbeleri sıradan, normal ve hatta pozitif bir eylem biçimi olarak değerlendirmesi sonucunu doğurabilir. Bazı dönemlerde militarist diskurların yoğunlaştığını, bazı dönemlerde ise azaldıklarını tespit eden mevcut araştırma, militarist diskurların eğitimdeki etkisinin doğrusal bir düzlemde artmadığı veya azalmadığı sonucuna varmıştır. AB üyelik reformları ile, eğitimde militarist diskurlar önemli ölçüde kaybolmasına rağmen, bunların gelecekte tekrar yankılanmayacă̆ının garantisi yoktur. Eğitim araştırmalarının bu konu üzerine yoğunlaşması, anti-demokratik diskurların eğitimde üretilmesini önlemek, sosyal eğitimi demokratikleştirmek ve demokrasi kültürünü geliştirmek açısından pozitif katkılar sunabilir.

\section{Katkısı Olanlar}

Makalenin yayım öncesi son halini inceleyerek, biçimsel değişiklik önerileri yapan Dr. Pelin Aksüt'e teşekkür ederim.

\section{Kaynaklar}

Aksan, H. (1958). Yurttaşlık bilgisi III. İstanbul: Ders Kitapları Türk Ltd. Şti.

Aksan, H. (1963). Yurttaşlık bilgisi III. İstanbul: Ders Kitapları Anonim Şirketi.

Akşit, N. ve Sanır, F. (1973). Sosyal bilgiler III. İstanbul: Ders Kitapları Anonim Şirketi.

Altınay, A. G. (2004). The myth of the military nation: Militarism, gender, and education in Turkey. New York: Palgrave Macmillan.

Altınay, A. G. (2009). Can veririm kan dökerim: Ders kitaplarından militarizm. G. Tüzün (Yay. haz.). Ders kitaplarında insan haklarl II: Tarama sonuçlarl, içinde (ss. 143-165). İstanbul: Tarih Vakfi Yayınları.

Altinyelken, H. K. (2015). Democratising Turkey through student-centred pedagogy: opportunities and pitfalls. Comparative Education, 51(4), 484-501. https://doi.org /10.1080/03050068.2015.1081794

Asal, T., Akşit, N. ve Sanır, F. (1975). Sosyal bilgiler III. Ankara: Türk Tarih Kurumu Basımevi. Asal, T., Akşit, N. ve Sanır, F. (1984). Sosyal bilgiler III (9. bs). İstanbul: Milli Eğitim Basımevi. Aşan, E. (2014). Vatandaşlık ve demokrasi eğitimi dersi 8. Ankara: Ekoyay.

Berkes, N. (1998). The development of secularism in Turkey. Londra: Routledge. 
Bernstein, B. (2003). The structuring of pedagogic discourse. Londra: Routledge.

Blad, C. ve Koçer, B. (2012). Political Islam and state legitimacy in Turkey: The role of national culture in neoliberal state-building. International Political Sociology, 6(1), 36-56. doi:10.1111/j.1749-5687.2012.00150.x

Burk, J. (2000). The citizen soldier and democratic societies: A comparative analysis of America's revolutionary and civil wars. Citizenship Studies, 4(2), 149-165. https://doi.org/10.1080/13621020050078069

Burk, J. (2002). Theories of democratic civil-military relations. Armed Forces and Society, 29(1), 7-29. https://doi.org/10.1177/0095327X0202900102

Celep, Ö. (2014). The political causes of party closures in Turkey. Parliamentary Affairs, 67(2), 371-390. https://doi.org/10.1093/pa/gss041

Cizre, Ü. (2011). Disentangling the threads of civil-military relations in Turkey: promises and perils. Mediterranean Quarterly, 22(2), 57-75. https://doi.org/10.1215/104745521263397

Cizre-Sakallığlu, Ü. (1997). The anatomy of the Turkish military's political autonomy. Comparative Politics, 29(2), 151. https://doi.org/10.2307/422077

Cizre-Sakallığlu, Ü. (2003). Demythologyzing the national security concept: the case of Turkey. Middle East Journal, 57(2), 213-229.

Cizre-Sakallığlu, Ü. ve Çınar, M. (2003). Turkey 2002: Kemalism, Islamism, and politics in the light of the February 28 process. The South Atlantic Quarterly, 102(2), 309-332.

Çiftçi, F., Yüksel, İ., Yıldız, R., Kıvrak, M., Öztürk, R., Cereno, A. ve Efe, F. (1999). Vatandaşlık ve insan hakları eğitimi ders kitabı 8 (1. bs). Ankara: MEB Devlet Kitapları.

Çiftçi, F., Yüksel, İ., Yıldız, R., Kıvrak, M., Öztürk, R., Cereno, A. ve Efe, F. (2004). Vatandaşlık ve insan hakları eğitimi ders kitabı 8 (1. bs). Ankara: MEB Devlet Kitapları.

Dal, K., Çakıroğlu, O. ve Özyazgan, A. İ. (1986). Vatandaşlık bilgileri III (2. bs). Ankara: Milli Eğitim Basımevi.

Dal, K., Çakıroğlu, O. ve Özyazgan, A. İ. (1994). Vatandaşlık bilgileri III (10. bs). İstanbul: Milli Eğitim Basımevi.

Fairclough, N. (2010). Analysing discourse: Textual analysis for social research. Londra: Routledge.

Hale, W. (2003). Human rights, the European Union and the Turkish accession process. Turkish Studies, 4(1), 107-126. https://doi.org/10.1080/714005714

Heater, D. B. (2004). A history of education for citizenship. Londra: Routledge.

Jenkins, G. (2007). Continuity and change: prospects for civil military relations in Turkey. International Affairs, 83(2), 339-355. https://doi.org/10.1111/j.1468-2346.2007.00622.x

Kancı, T. ve Altınay, A. G. (2007). Educating little soldiers and little Ayşes: Militarised and gendered citizenship in Turkish textbooks. M. Carlson, A. Rabo ve F. Gök (Yay. haz.), Education in "multicultural societies"-Turkish and Swedish perspectives, içinde(ss. 5170). Stockholm: Roos Tryckerier AB.

Kanci, T. (2009). Reconfigurations in the discourse of nationalism and national identity: Turkey at the turn of the twenty-first century. Studies in Ethnicity and Nationalism, 9(3), 359376. https://doi.org/10.1111/j.1754-9469.2009.01057.x

Kaplan, S. (2002). Din-u devlet all over again? The politics of military secularism and religious militarism in Turkey following the 1980 coup. International Journal of Middle East Studies, 34(01), 113-127.

Kaplan, S. (2005). "Religious nationalism": A textbook case from Turkey. Comparative Studies of South Asia, Africa and the Middle East, 25(3), 665-676.

Kaplan, S. (2006). The pedagogical state: Education and the politics of national culture in Post1980 Turkey. Redwood City, CA: Stanford Üniversitesi Yayınevi.

Karaosmanoğlu, A. L. (2000). The evolution of the national security culture and the military in Turkey. Journal of International Affairs, 54(1), 199-216.

Lewis, B. (2002). The emergence of modern Turkey (3rd ed). Oxford: Oxford Üniversitesi Yayınevi. 
Millî Eğitim Bakanlığı. (1985, Nisan 26). Ortaokul sosyal bilgiler dersinin Milli Tarih, Milli Coğrafya ve Vatandaşlık Bilgisi adları ile üç ayrı ders olarak okutulması. Talim Terbiye Kurulu Başkanlığı Arşivi.

Millî Eğitim Bakanlığı. (1995). Vatandaşlık ve insan hakları eğitimi dersi” programı ile ilgili değişikliklerin kabulü. Millî Eğitim Bakanlı̆̆ Tebliğler Dergisi, 58(2437), 696-698.

Millî Eğitim Bakanlığı. (2005). İlköğretim okulu haftalık ders çizelgesi. Millî Ĕgitim Bakanlı̆̆ Tebliğler Dergisi, 68(2575), 539-541.

Millı̂ Eğitim Bakanlığı. (2012). İlköğretim kurumları (İlkokul ve Ortaokul) haftalık ders çizelgesi. Millı Eğitim Bakanlığı Tebliğler Dergisi, 75(2658), 314-316.

Millî Eğitim Bakanlığı. (2010). İlköğretim okulu haftalık ders çizelgesi. Millî Ĕgitim Bakanlı̆̆ Tebliğler Dergisi, 73(2635), 1539-1545.

Merriam, S. B. (2009). Qualitative research: a guide to design and implementation. San Francisco: Jossey-Bass.

Ozgur, I. (2012). Islamic schools in modern Turkey: faith, politics, and education. Cambridge: Cambridge Üniversitesi Yayınevi.

Özdalga, E. (1999). Education in the name of "order and progress" reflections on the recent eight year obligatory school reform in Turkey. The Muslim World, 89(3-4), 414-438. https://doi.org/10.1111/j.1478-1913.1999.tb02756.x

Özpolat, V. (Ed.). (2012). Vatandaşllk ve demokrasi eğitimi: Ders kitabi 8 (2. bs). Ankara: MEB.

Özyürek, E. (2006). Nostalgia for the modern: State secularism and everyday politics in Turkey. Durham, North California: Duke Üniversitesi Yayınevi.

Sen, A. (2018). Militarisation of citizenship education curriculum in Turkey. Journal of Peace Education, 1-26. https://doi.org/10.1080/17400201.2018.1481019

Sen, A., ve Starkey, H. (2017). The rise and fall of citizenship and human rights education in Turkey. Journal of Social Science Education, 16(4), 84-96. https://doi.org/10.4119 /UNIBI/jsse-v16-i4-1689

Şerbetçioğlu, F. ve Tülin, H. (1958). Yurttaşlık bilgisi III. Ankara: Maarif Basımevi.

Şerbetçioğlu, F. ve Tülin, H. (1962). Yurttaşlık bilgisi III. Ankara: Milli Eğitim Basımevi.

Tanır, A. (1997). Vatandaşlık ve insan haklarl eğitimi 8. Ankara: Özgün Matbaacılık.

Türkiye Büyük Millet Meclisi. (1982). Türkiye Cumhuriyeti Anayasası. Erişim adresi: https://www.tbmm.gov.tr/anayasa/anayasa82.htm.

Üstel, F. (2004). Makbul vatandaş'ın peşinde: II. Meşrutiyet'ten bugüne Türkiye'de vatandaşlık eğitimi (1. bask1). İstanbul: İletişim Yayınları.

Van Leeuwen, T. (2007). Legitimation in discourse and communication. Discourse ve Communication, 1(1), 91-112. https://doi.org/10.1177/1750481307071986

van Dijk, T. A. (1998). Ideology: a multidisciplinary approach. Londra: SAGE Publications.

Yavuz, M. H. (1999). The assassination of collective memory: The case of Turkey. The Muslim World, 89(3-4), 193-207. https://doi.org/10.1111/j.1478-1913.1999.tb02744.x

Yiğit, U. (2007). Vatandaşlık ve insan hakları eğitimi ders kitabı 8. İstanbul: Batu Yayıncılık.

Yiğit, U. ve Turan, T. (1996). Vatandaşlık ve insan hakları eğitimi 8. İstanbul: Bu Yayınevi.

Zürcher, E. J. (2005). How Europeans adopted Anatolia and created Turkey. European Review, 13(03), 379-394. https://doi.org/10.1017/S1062798705000529

\section{Extended Abstract}

\section{Introduction}

The Turkish military, one of the significant actors in Turkey's nationalisation and modernisation history, has had a dominant position within the democratic state system of Turkey. Its political autonomy in the system and interventions in politics have not complied with the norms and principles of established democracies. By using public discourse production means like education, the military has attempted to normalise and legitimise its anti-democratic status and behaviours that constitute an anomaly according to democratic norms. A part of studies has 
focused on exploring ways in which the military was instrumentalised education to disseminate an official ideology and how the changing versions of nationalism supported by the military were echoed in education (Kaplan, 2002, 2005, 2006; Özdalga, 1999; Sen \& Starkey, 2017; Yavuz, 1999). Another group has explored how "values, practices, processes and approaches concerning army and military service!" were diffused into everyday life through education and came to be regarded as natural (Altınay, 2009, p. 144). This second group studies aimed to demonstrate where discourses, such as the Turkish nation is a military nation, were originated and how they were infused into textbooks and became fact-like social beliefs (Altınay, 2004; Kancı \& Altınay, 2007). These studies criticised the glorification of militarism in education and argued that it harms democracy and human rights values. However, these studies have not explored ways in which militarist discourses normalising the military's anti-democratic status and behaviours have been re-produced via social education.

\section{Method}

In this research, militarist discourse is defined as attempts to normalise, legitimise and even glorify the political autonomy of the military within the state system and the military's interventions that either disrupted or harmed the functioning of Turkey's democratic order. Based on this definition, the present research aims to illustrate how discourses that belong to the institutional realm of the military were resonated in education by providing a critical discourse analysis of 16 middle school $\left(8^{\text {th }}\right.$ grade) citizenship and social studies textbooks, which were taught from 1950 to 2012. The version of critical discourse analysis drawn on in this research is developed by van Dijk (1998), Fairclough (2010) and Van Leeuwen (2007) for social research purposes. The militarist discourses embedded in the textbooks were brought into open by utilizing the analytical tools developed by these critical discourse analysts.

\section{Findings and Discussion}

The study revealed that one dominant discourse that found its expression in the textbooks presents the army as an inseparably organic part of the Turkish nation in the following way: "The Turkish army is the genuine child of the Turkish nation and its armed wings [silahlı kollarl]" (Şerbetçioğlu \& Tülin, 1958, p. 75). No organic relations like the one between the army and the nation is established for other institutions like for the parliament. This organic relation provides a basis for emphasising the army's vitality and justifying its political autonomy and interventions in politics by implying that the military is true representative or soul of the Turkish nation and its antidemocratic behaviours like staging coups are necessary and legitimate. From this perspective, the military coups are presented, especially in the post-coup period textbooks, as legitimate, laudable and liberating actions as though they were supported by the whole nation. This militarist discourse went through important changes without showing a linear decline or rise from 1950 to 2012. It culminated in the post-1997 coup years, but after the 1999 Helsinki Summit, began to go down and disappeared to a great extent in the 2010s. Before its disappearance, the study found that the militarist discourses had been with varying strategies normalised, justified and even glorified the military's anti-democratic positions and behaviours until the 2005 curriculum reform was undertaken.

The present research's findings support the previous studies that the 2005 curriculum reform aiming to establish student-centred instruction in the Turkey's educational system made a positive impact on democratic practices and reduced the signs of the militarist discourse in education (Altinyelken, 2015; Kanc1 \& Altınay, 2007; Kanc1, 2009). When we set aside the last period of de-militarisation, the militarist discourse was less prominent in the textbooks from 1968 to 1985 , which was also pointed out by Üstel (2004). Social education's dissemination of discourses that legitimise the military's anti-democratic status and actions are detrimental to democracy education and the improvement of the culture of democracy in Turkey. The present study showed that discourses that are associated with the institutional ideology of the military have not gone down or up in a linear way. Even though the EU membership reforms played a decisive role in clearing the textbooks from the militaristic discourses, it is not certain that they 
Ders Kitaplarında Asker-Sivil İlişkileri ve Darbeler

will not make a comeback in future. Conducting research to demonstrate how militaristic discourses are re-produced through education can contribute to both the democratisation of social education and the improvement of the culture of democracy in Turkey. 